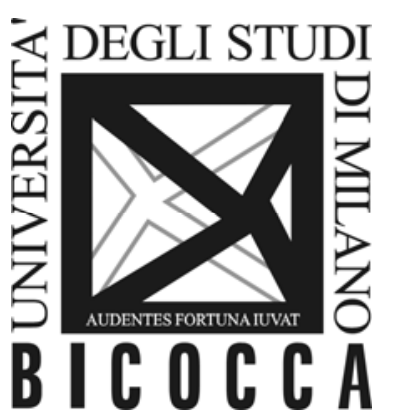

\author{
DEPARTMENT OF ECONOMICS, \\ MANAGEMENT AND STATISTICS \\ UNIVERSITY OF MILAN - BICOCCA
}

DEMS WORKING PAPER SERIES

\title{
Estimating sourcing premia with Italian regional data
}

\author{
Valeria Gattai, Valentina Trovato
}

No. 276 - June 2014

Dipartimento di Economia, Metodi Quantitativi e Strategie di Impresa Università degli Studi di Milano - Bicocca 


\title{
ESTIMATING SOURCING PREMIA WITH ITALIAN REGIONAL DATA
}

Valeria Gattai (corresponding author)

Università di Milano-Bicocca, DEMS

Piazza Ateneo Nuovo 1

20126 Milan (Italy)

Tel: +390264483224

Fax: +390264483085

Email address: valeria.gattai@unimib.it

Valentina Trovato

Università di Milano-Bicocca

Piazza Ateneo Nuovo 1

20126 Milan (Italy)

\begin{abstract}
This paper explores the link between sourcing and performance for a representative sample of manufacturing firms located in Lombardy, the leading economic region in Italy. Survey estimation methods, applied to the authors' original database, reveal that there exist some performance premia for firms engaged in foreign, rather than domestic and in- rather than out- sourcing. This result is robust to different specifications, samples, performance measures and definitions of sourcing strategies.
\end{abstract}

JEL: D23, F23, L23

KEYWORDS: Sourcing, Premia, Regional data, Manufacturing industry, Italy

\section{ACKNOWLEDGEMENTS}

Data have been gathered with the help of Maria Luisa Mancusi, to whom we are indebted. Valeria Gattai gratefully acknowledges financial support from Università di Milano-Bicocca and MIUR (Italian Ministry of Education University and Research). All remaining errors are the authors' responsibility. 


\section{INTRODUCTION}

Over the last few decades, the world economy and the firm itself have become the theatre of a massive reorganization, whose keywords sound like integration of trade and disintegration of production (Feenstra, 1998).

Trade economists agree on the fact that a new feature of globalization is the dramatic increase in Foreign Direct Investment (FDI) and trade in intermediate components which, in turn, reflects the new way firms organize their activities. Since 1990 s, more than $40 \%$ of US imports of goods have taken place within the boundaries of multinational enterprises (Zeile, 1997) and roughly one third of world trade now occurs intra firm (Antras, 2003; Helpman, 2006).

As some regional economists have recently remarked, new millennium organizations have successfully proved their ability to cross territories and frontiers. Even though they are situated in a space, they are not defined or limited by it at all. On the contrary, space becomes a key ingredient to take into account when deciding about firms' boundaries (Torre and Rallet, 2005).

Stimulated by the lively debate on these issues, the present paper explores the link between sourcing and performance for a representative sample of manufacturing enterprises located in Lombardy, the leading economic region in Italy.

In selecting this topic, we draw on two main facts.

First, firms committed to global markets take crucial decisions over their boundaries, namely they choose which tasks should be performed intra or extra firm, in the domestic or in a foreign market. As a result of firms' ownership and location solutions, four sourcing modes emerge, called domestic integration (DI), domestic outsourcing (DO), foreign integration (FI) and foreign outsourcing (FO) ${ }^{1}$. The well established theoretical literature on global sourcing under contractual incompleteness studies the reason why firms should opt for a given organizational mode, and makes predictions about the type of firms that is more likely to choose one mode over the others (for a survey see: Spencer, 2005; Antras and Rossi-Hansberg, 2009; Antras, 2014). In particular, most productive players are shown to prefer foreign rather than domestic and in- rather than outsourcing, both in the theoretical models and in a few empirical studies that have recently tested 
Antras and Helpman (2004, 2008) with firm-level data (see, among others: Tomiura, 2007b; Federico, 2010; Kohler and Smolka, 2011, 2012).

Second, globally engaged enterprises turn out to be a minority, compared with the whole population of national firms, but they perform better on a number of performance variables. This, in turns, points to the existence of some internationalization premia that make firms engaged in international business larger, more productive, more capital intensive etc. than purely domestic players. Starting from the seminal contribution of Bernard and Jensen (1995), a burgeoning empirical literature has gone deep into the issue of internationalization and performance at the micro level, providing very consistent results, despite the year and the country where the analysis is set (for a survey, see: Lopez, 2005; Wagner, 2007, 2012; Greenaway and Kneller, 2007; Singh, 2010; Hayakawa and Machikita, 2012).

Based on these two facts, we ask: is there any systematic performance difference among firms, depending on their sourcing behaviour? Are firms selecting a given organizational mode different from the others? Notice that, in asking these questions, we do not aim at testing any specific model of sourcing, but rather at integrating the two strands mentioned above. From the literature on global sourcing under contractual incompleteness, we derive the basic taxonomy of organizational solutions and the prior according to which most productive firms have a preference for vertical integration and foreign location. From the literature on internationalization and performance at the micro level we derive some insights about performance measures and the prior according to which globally engaged enterprises are better than their domestic counterparts. In the end, we pursue an open search for sourcing premia, looking for correlations between organizational modes - out of those identified from the first strand - and economic performance - measured through the whole set of variables available under the second one.

The answer we provide is an empirical one, based on original survey data collected by the authors for a representative sample of manufacturing enterprises located in Lombardy, the economic core of Italy. What we find is that there exist some performance differences among firms enjoying different 
sourcing solutions. Survey estimation methods reveal indeed that foreign rather than domestic and in- rather than out- sourcing entails significant size, value added, capital, productivity, profit and skill intensity premia for Lombard enterprises. This result is broadly consistent with previous studies on global sourcing under contractual incompleteness and internationalization and performance at the micro level. Moreover, it is robust to different specifications, samples, performance measures and definitions of sourcing strategies.

To the best of our knowledge, this study discloses a few novelties, compared with the existing literature. First, our research question is rather new and it goes beyond previous attempts at testing Antras and Helpman (2004, 2008)'s mapping of heterogeneous firms into sourcing strategies, due to Tomiura (2005, 2007a, 2007b, 2009), Ito, Tomiura, and Wakasugi (2011), Defever and Toubal (2013), Corcos et al. (2013), Federico (2010) and Kohler and Smolka (2011, 2012). Even though these studies incidentally estimate some sourcing premia, most of them consider only a subset of sourcing strategies and focus only on productivity; on the contrary, we deal with the whole set of organizational modes and explore a much broader array of performance variables. Second, we employ an original database, designed specifically to analyze sourcing premia. These data enable us to make some important steps along our declared research agenda. For instance, we are allowed to: a) disaggregate firms' production process into different tasks; b) associate each firm to its respective sourcing choice for every task performed along its production process; c) identify true headquarter firms, namely those actually responsible for their sourcing behaviour ${ }^{2}$. While point c) has already been remarked in Kohler and Smolka $(2011,2012)$, points a) and b) sound completely new, resulting in a more comprehensive characterization of sourcing premia, compared with previous firm-level studies. Last but not least, we provide original evidence about Italian enterprises, complementing previous empirical studies on related issues, based on national (Federico, 2010) or regional (Cusmano, Mancusi, and Morrison, 2009, 2010) data from the same country. On the one hand, comparing our evidence with Federico (2010), we expect to disentangle the regional versus national component of sourcing premia and see whether there is something special of Lombard 
enterprises vis-à-vis with the Italian aggregated picture. On the other hand, adding ownership to the location choice, already analyzed in Cusmano, Mancusi, and Morrison (2009, 2010), we revisit their empirical evidence and see whether a positive correlation between international outsourcing and performance is really a matter of FO, or it simply depends on the international (instead of domestic) attitude or outsourcing (instead of integration) behaviour of Lombard firms.

The rest of the paper is organized as follows. Section 2 makes a brief a literature review; Section 3 provides some data description; Section 4 defines sourcing strategies and comments some descriptive statistics about them; Section 5 is completely devoted to the econometric analysis, while Section 6 concludes and sets future lines of research.

\section{LITERATURE REVIEW}

In this section, we briefly review the two strands of the literature that inspire the present research.

\section{Global Sourcing under Contractual Incompleteness}

For the sake of simplicity, consider a very stylized framework in which a firm is willing to produce a final good; final good production requires two tasks - input manufacturing and final good processing - and the enterprise itself is responsible for processing. Under these assumptions, the firm can either manufacture components within its boundaries or it can purchase them from an independent supplier; moreover, inputs can be made-or-bought either in the home or in the host country. Depending on whether the input supplier is a domestic or a foreign enterprise, and whether it belongs to the firm or not, four sourcing strategies may emerge, namely DI, DO, FI and FO (Antras and Helpman, 2004) ${ }^{3}$.

Which factors affect firms' sourcing behaviour? Which type of firms opts for a given organizational mode? In what follows, we briefly review the theoretical and empirical answers to these questions. As for the theoretical approach, one candidate explanation of global sourcing stems from the wish to mitigate hold-up concerns in a context of contractual incompleteness. 
The original intuition of Grout (1984), Grossman and Hart (1986) and Hart and Moore (1990) is extended to the international context in McLaren (2000), Grossman and Helpman (2002, 2003, 2005), Antras (2003), Ottaviano and Turrini (2007), and Antras and Helpman (2004, 2008)

A maintained framework across these models is that a firm, located in the North, is the final good producer and that final good production requires relation-specific investments to manufacture components. What differs is, instead, the number of sourcing strategies that are analyzed. In particular, McLaren (2000) and Grossman and Helpman (2002) focus on DI versus DO, Grossman and Helpman (2005) on DO versus FO, Grossman and Helpman (2003), Antras (2003) and Ottaviano and Turrini (2003) on FI versus FO, while Antras and Helpman (2004, 2008) $)^{5}$ are the only contributions offering the full characterization of all sourcing modes in a unitary framework.

Despite the subset of strategies considered in the different papers, a common message emerges from this theoretical literature. In choosing between integration and outsourcing, firms trade off the benefits of ownership under vertical integration, with the benefits of better incentives for the manufacturer under arm's length trade. In choosing between domestic and foreign strategies, final good producers trade off the benefits of lower variable costs in the South with the benefits of lower fixed organizational costs in the North. Interacting these effects, one obtains a clear picture about the main factors affecting firms' sourcing behaviour.

Another interesting question regards which firms are more likely to choose a specific sourcing strategy rather than the others. Clearly, this issue can be addressed only in a heterogeneous firm framework as in Antras and Helpman (2004, 2008). Building on Melitz (2003), they assume that, upon paying fixed entry costs, final good producers draw a productivity level from a known distribution; after observing that level, each of them decides whether to exit the market or to start producing. In the end, the two papers prove that in low tech sectors integration never occurs: lower productivity players choose DO, higher productivity players select FO. On the contrary, in high tech sectors, all sourcing strategies may be undertaken: lower productivity firms buy inputs in the domestic market, higher productivity firms buy inputs in the foreign market; among firms sourcing 
in the same country, more productive ones vertically integrate, less productive outsource. These results provide clear-cut predictions about firms' sorting into different sourcing modes. Put another way, firms are expected to self-select into one of the four mutually exclusive alternatives - DO, DI, FO and FI - depending on their productivity level.

In the last few years, a burgeoning empirical literature has grown fast, to bring Antras and Helpman (2004, 2008)'s intuition close to the data. The availability of large longitudinal datasets at the micro level have recently disclosed interesting findings about productivity and sourcing behaviour, offering a preliminary test of some theoretical results, adding to previous industry-level evidence (Antras, 2003; Nunn and Trefler, 2008, Yeaple, 2006; Federico, 2012; Bernard et al., 2010).

Empirical papers of this sort differ in terms of sourcing modes and geographical coverage. As for the first issue, most studies consider only a subset of strategies, depending on data availability. For instance, Tomiura $(2005,2009)$ and Ito, Tomiura, and Wakasugi (2011) focus on FO versus DO, Tomiura (2007a), Defever and Toubal (2013) and Corcos et al. (2013) study FO versus FI while Tomiura (2007b), Federico (2010) and Kohler and Smolka (2011, 2012) are the only papers considering all strategies in the same econometric model, capturing the original spirit of Antras and Helpman $(2004,2008)$. As for the geographical coverage, existing studies provide some evidence only for Japan (Tomiura, 2005, 2007a, 2007b, 2009; Ito, Tomiura, and Wakasugi, 2011), France (Defever and Toubal, 2013; Corcos et al., 2013), Italy (Federico, 2010) and Spain (Kohler and Smolka, 2011, 2012).

Despite these differences, some important regularities also emerge throughout the empirical literature. First, heterogeneity is measured quite consistently, in terms of labour or total factor productivity; second, results are quite alike: firms sourcing abroad are, on average, better than firms sourcing domestically; moreover, vertically integrated enterprises are, on average, better than outsourcers. By and large, these findings are consistent with the theoretical framework due to Antras and Helpman $(2004,2008)$ since most productive firms choose FI, least productive ones opt for DO. However, no definite ranking emerges encompassing all sourcing strategies, because firms 
with intermediate levels of productivity self select either into DI or FO (see, for instance: Federico, 2010; Kohler and Smolka, 2011). Hence, the theoretical sorting of firms into sourcing modes is preserved only at the extremes.

\section{Internationalization and Performance at the Micro Level}

Starting from the seminal contribution of Bernard and Jensen (1995), scholars all over the world have begun to investigate the relationship between internationalization and performance at the micro level ${ }^{6}$.

They document that globally engaged enterprises tend to be a minority, compared with purely domestic players, but they perform better on a number of economic variables - including size, wage, value added, productivity etc.

They also suggest two alternative - although not mutually exclusive - explanations why firms involved in international business could be better than domestic enterprises. Under the so called self-selection argument, there are ex-ante performance differences between firms that will become international and firms that will keep serving the domestic market. The intuition is that operating abroad involves additional costs - related to transportation, marketing, human capital and production - that provide a natural entry barrier to less successful firms. Hence, causality runs from performance to internationalization, meaning that only better enterprises self-select into the international arena, being able to afford the extra costs of international business ${ }^{7}$.

Under the so called learning-by-internationalization argument, ex-post performance differences emerge, instead, as a result of firms' exposure to the international market. This is because, interacting with foreign competitors and customers, firms derive information about reducing costs and quality rising processes; moreover, to keep pace with their rivals, they are strongly encouraged to innovate, increase their scale, and become more efficient. For all these reasons, globally-engaged enterprises are likely to improve faster than their domestic counterparts, i.e. causality runs from internationalization to performance. 
Since Bernard and Jensen (1995), a fast growing empirical literature has gone deep into these issues, identifying some typical internationalization premia, defined as the average percentage difference in performance between internationalized versus domestic players. If the first contributions based only on US data, large longitudinal datasets have recently become available also in Europe, triggering new academic research on the topic. Among European countries, Italy counts for an exceptionally wide range of firm-level data sources and so it provides a privileged locus to test Bernard and Jensen (1995)'s intuition.

In what follows, we focus more specifically on the papers about internationalization and performance of Italian enterprises, to allow for comparability of results with Section 4 and Section 5, where we present original evidence from the same geographical area. For expositional convenience, we review the related literature according to the following issues. First, we draw the overall picture of Italian firms' global involvement, considering the relative prevalence of different internationalization strategies; second we discuss the main internationalization premia, as highlighted in the existing studies.

As far as the first issue is concerned, evidence provides some clear-cut results. Italian firms are active on a number of internationalization strategies, ranging from import to export, from FDI to international outsourcing, from international partnerships to subcontracting. If one considers all these strategies together, global firms turn out to the majority, compared with purely domestic players (Basile, Giunta, and Nugent, 2003; Benfratello and Razzolini, 2009; Castellani and Zanfei, 2007). If one considers, instead, one strategy at a time, different patterns emerge. In particular, exporters and importers tend to be quite numerous, entailing more than $50 \%$ of the entire population (see, among others: Crinò and Epifani, 2012; ISGEP, 2008; Razzolini and Vannoni, 2011; Serti and Tomasi, 2008b, 2012; Serti, Tomasi, and Zanfei, 2010). On the contrary, firms engaged in FDI represent just a minority, accounting for less than $10 \%$ of the overall samples (Barba Navaretti et al., 2011; Casaburi; Gattai, and Minerva, 2007; Castellani and Giovannetti, 2010; Giovannetti, 
Ricchiuti, and Velucchi, 2009), and the same applies to international outsourcing (Barba Navaretti et al., 2011; Casaburi, Gattai, and Minerva, 2007).

As far as the second issue in concerned, the great bulk of the literature emphasizes the existence of some internationalization premia related to foreign exposure of Italian enterprises ${ }^{8}$. This means that globally engaged players are better than domestic actors on a number of economic, innovation and financial variables. Notably, each category of foreign involvement entails some performance advantages compared with purely domestic operations (see, among others: Basile, 2001; Bratti and Felice, 2012; Castellani, 2007; Mayer and Ottaviano, 2007). Furthermore, a systematic performance ranking emerges for players characterized by different degrees of internationalization, or pursuing more than a single strategy, with FDI makers at the top and exporters at the bottom of the distribution (see, for instance: Benfratello and Razzolini, 2009; Casaburi, Gattai, and Minerva, 2007; Castellani and Zanfei, 2007; Serti and Tomasi, 2008b, 2012; Castellani, Serti, and Tomasi, 2010; Mayer and Ottaviano, 2007; Castellani and Giovannetti, 2010). Last but not least, there is evidence both in favour of self-selection and learning-by-internationalization. This suggests that better Italian firms tend to operate abroad but, at the same time, operating abroad is likely to foster their economic performance (see, for instance: Basile, 2001; Bratti and Felice, 2012; Castellani and Giovannetti, 2010; Ferragina and Quintieri, 2001; ISGEP, 2008; Serti and Tomasi, 2008a, 2012).

\section{DATA}

The present study draws on an original survey conducted by the authors between 2010 and 2011 and involving a representative sample of manufacturing firms located in Lombardy, the leading economic region in Italy. Lombardy accounts for $28 \%$ of total Italian export and $31 \%$ of import; it involves $49 \%$ of inward FDI and $35 \%$ of outward FDI and it contributes to $21 \%$ of value added, $21 \%$ of GDP and $29 \%$ of patent applications (ASR, 2013). Moreover, the region exhibits a mature and highly heterogeneous industrial system, where large high-tech corporations coexist with traditional small and medium enterprises (Garofoli, 1983; Corò and Grandinetti, 1999; Garofoli, 
2002; Cusmano and Malerba, 2005). For all these reasons, we believe it is a suitable locus to investigate the relationship between sourcing and performance, in a context of heterogeneity.

Our target sample of 300 firms is drawn from the national firm Census (ISTAT, 2001) and it is stratified according to geographical location, manufacturing activity and firm size. Geographical location stratification bases on four macro areas that group neighbouring provinces according to their productive specialization; they are called: North-West (including Como, Lecco, Varese), North-East (including Bergamo, Brescia, Sondrio), South-West (including Lodi, Milano, Monza Brianza, Pavia) and South-East (including Cremona, Mantova). Manufacturing activity stratification follows Bell and Pavitt (1993)'s taxonomy that groups industries into four macro categories according to the source of technology and technical change; they are called: traditional supplier dominated, specialized supplier dominated, science based and scale intensive ${ }^{9}$. Firm size stratification builds of the number of employees and it is based on three main cells; they include firms with less than 50 employees, firms with 50-249 employees and firms with more than 249 employees.

The number of firms in each stratum of the target sample was obtained assuring proportionality to the total number of firms in the same stratum of the population.

All firms were contacted by phone, and then a multiple-choice questionnaire was submitted by email $(70 \%)$ or fax $(30 \%)$ to senior managers and CEOs.

The questionnaire is made up of two sections: first we ask background information about the local firms, including balance sheet details and intangible assets; second, we investigate their sourcing behaviour and international experience. Data collected with the first section of the questionnaire cover the period 2005-2009, while data collected with the second one refer only to 2007 . This is because we tried to exclude any financial crises effect on sourcing behaviour and international experience, while benefiting from a longer time span in terms of performance variables.

With a response rate of $76 \%$, this study provides a detailed picture of 228 firms located in Lombardy. As shown in Table 1, our sample is highly representative of the entire population. 
[Insert Table 1 about here]

Before moving to the empirical analysis, we believe it is worth making a few comments on the sample composition, to derive some basic facts.

As far as the geographical location is concerned, most firms come from the South-West of the region (36.4\%), followed by the North-East (30.26\%), the North-West $(26.75 \%)$ and the tail-end South-East (6.58\%). This suggests that the manufacturing core of Lombardy is centred on Lodi, Milano, Monza Brianza and Pavia, while Cremona and Mantova account for a limited share of local business.

As for the manufacturing activity, scale intensive operations turn out to be the main economic activity, involving $46.49 \%$ of the sampled firms. They are followed quite closely by supplier dominated (32.46\%), while specialized supplier dominated $(16.23 \%)$ and science based $(4.82 \%)$ industries come far beyond. These data confirm that the industrial texture of the region is highly diversified, with multiple specializations leading to a balanced mixture of traditional and high-tech activities.

Lastly, with respect to firm size, our sample is characterized by the striking prevalence of small enterprises $(94.9 \%)$ with less than 50 employees. On the contrary, medium and large firms account for a limited $4.14 \%$ and $0.96 \%$ of the total. Given the well documented relevance of Lombardy for the Italian economy, this suggests that a mass of small and medium enterprises, rather than a handful of huge conglomerates, is responsible for remarkable shares of national value added, GDP, export, import and FDI.

\section{DEFINTION OF SOURCING STRATEGIES AND DESCRIPTIVE STATISTICS}

In this section we provide a detailed definition of sourcing strategies and comment some descriptive statistics, to portray Lombard firms' global sourcing.

Definition of Sourcing Strategies 
Defining sourcing strategies in a proper way is crucial to the present study. This was clear to the authors from the very beginning, when they set up the questionnaire. In particular, they faced a trade-off between being consistent with the theory, to provide easy to interpret results, and going beyond the theory itself, to reach a better understanding of global sourcing and eventually disclose new evidence. Put another way, the issue was how to translate the theoretical definition of sourcing strategies into a convenient empirical proxy.

According to the theory, firms uniquely map into four mutually exclusive sourcing strategies called DO, DI, FO and FI - depending on their ownership (make versus buy) and location (home versus foreign) responses to input procurement concerns. As mentioned in Section 2, this is the result of two simplifying assumptions: first, the production process involves only two tasks - input manufacturing and final good processing; second, final good processing always rests with the firm in the home country, while inputs can be made or bought, domestically or abroad.

In designing the questionnaire, we relaxed those assumptions in such a way as to provide a richer taxonomy of sourcing strategies, while preserving the stylized theoretical framework as a special case.

More precisely, we disaggregate the production process into four, rather than two, tasks including input manufacturing, final good processing, Research \& Development (R\&D) and other services (informative, logistics etc.). Moreover, we allow firms to take the ownership and location decisions for every task performed along their production process, not only for input manufacturing.

To avoid ambiguity as to the precise meaning of the various organizational forms, we list below the exact questions to which firms were responding in the questionnaire (Figure 1).

[Insert Figure 1 about here]

Columns of Figure 1 represent the four tasks eventually performed along firms' production process; rows characterize instead firms' sourcing behaviour. To provide a rich and comprehensive taxonomy of global sourcing, for every task, we ask firms to which extent that task occurs within their boundaries, within the boundaries of a foreign affiliate, within the boundaries of an 
independent Italian firm, and within the boundaries of an independent foreign firm. At this stage it is worth noting that these are not mutually exclusive categories, meaning that the same task may be performed both domestically and abroad, both inside and outside the firm. We believe this is another interesting departure from the stylized framework delineated in Section 2.

From the information collected through question 2.5 in the questionnaire, we give four different definitions of sourcing strategies.

First, we distinguish between the so called "conservative" and "liberal" definition of DO, DI, FO and FI. Consistently with the theory, the "conservative" definition focuses only of input manufacturing. Hence, firms are said to engage in DI, according to the conservative definition, when they perform a positive fraction of input manufacturing within their boundaries; to engaged in FI when they perform a positive fraction of input manufacturing within the boundaries of a foreign affiliate; in DO when they perform a positive fraction of input manufacturing within the boundaries of an independent Italian firm; in FO when they perform a positive fraction of input manufacturing within the boundaries of an independent foreign firm. Firms are said to be no sourcing (NS) in a conservative way when they do not perform input manufacturing at all. Differently from the theory, the "liberal" definition focuses on all production tasks but final good processing. The rational for that is to extend the notion of intermediate goods, as to include some strategic assets like R\&D and other services adding to more traditional inputs. Thus, firms are said to engage in DI, according to the liberal definition, when they perform a positive fraction of input manufacturing or R\&D or other services within their boundaries; to engaged in FI when they perform a positive fraction of input manufacturing or R\&D or other services within the boundaries of a foreign affiliate; in DO when they perform a positive fraction of input manufacturing or R\&D or other services within the boundaries of an independent Italian firm; in FO when they perform a positive fraction of input manufacturing or R\&D or other services within the boundaries of an independent foreign firm. Firms are said to be NS in a liberal way, when they do not perform input manufacturing, R\&D and other services at all. The main advantage of the conservative definition is that results are likely to be 
neat, and easy to confront with the theoretical priors; however, it exploits only part of the information collected through survey interviews, offering a somewhat standard treatment of sourcing strategies. The liberal definition makes, instead, a more general overview of firms' organizational solutions and, taking advantage of the rich dataset, it might disclose new facts about global sourcing; however, it is not obvious how to evaluate its results according to the theory. To the best of our knowledge, this is the first paper introducing the distinction between conservative and liberal modes, while Federico (2010), Tomiura (2007b), Kohler and Smolka (2011, 2012) only deal with the former.

Second, we distinguish between the so called "mutually inclusive" and "mutually exclusive" definition of sourcing strategies. In the first case, we assign each firm any sourcing strategy that results from interviews, meaning that the same enterprise may be active in more than a single strategy. In the second case, each firm is assigned only one sourcing strategy, so that the total number of sourcing firms equals the total number of sourcing strategies. Following closely Kohler and Smolka (2011), when a firm is active in two or more sourcing modes simultaneously, it is assigned the least prevalent category in the overall sample ${ }^{10}$. The main advantage of the mutually inclusive definition is that it preserves all information coming from the data; however, results might be difficult to interpret in light of the theoretical models. The mutually exclusive definition is, instead, more arbitrary in that authors make a choice regarding which strategy, out of a set, should be assigned to each firm; however, results are likely to be clear-cut, and easy to confront with the theoretical predictions.

In light of the above discussion, since each definition entails some pros compared with the others, we prefer keeping all of them for empirical purposes. This eventually enables us to make comparisons and reach a better understanding of global sourcing.

In what follows, we stick to the labels of: "liberal definition of mutually inclusive sourcing strategies", "conservative definition of mutually inclusive sourcing strategies", "liberal definition of mutually exclusive sourcing strategies" and "conservative definition of mutually exclusive sourcing 
strategies" to denote the four instances discussed above. While the first case is the most general, the last one restores the stylized theoretical framework of Section 2.

\section{Descriptive Statistics}

Table 2 disaggregates sampled firms into sourcing strategies. At this stage, firms are simply mapped into all possible combinations of DO, DI, FO and FI, to provide a first look at the data.

[Insert Table 2 about here]

According to the conservative definition, NS firms represent just $25 \%$ of the overall sample, while sourcing firms, namely those selecting one out of 15 combinations of DO, DI, FO and FI account for the vast majority.

If we look at pure strategies ${ }^{11}$, DI is the most frequent choice, followed by DO, FO and FI respectively. This picture is strongly consistent with the Japanese one delineated in Tomiura (2007b), where the same ranking emerges; on the contrary, Kohler and Smolka $(2011,2012)$ report that Spanish enterprises are primarily active in DI, followed by FO, DI and FI, and the same is true for the sample of Italian firms analyzed in Federico $(2010)^{12}$. If we look, instead, at mixed strategies, the most frequent combination is DIDO that involves $42 \%$ of sourcing firms. Notice also that DI occurs quite often both alone and together with DO, FO and FI, while the other strategies tend to be chosen only as part of a mixed design. As for the ownership and location decisions, underlying firms' sourcing behaviour, Table 2 suggests that, in choosing between home and foreign, Lombard respondents tend to prefer home and, in choosing between make and buy, they tend to select make. Put another way, our respondents' answer to their input procurement question bases on in- rather than out- and domestic rather than foreign sourcing.

Results are quite alike if we move from the conservative to the liberal definition. The only remarkable difference concerns the proportion between sourcing and no sourcing firms since the liberal definition, by construction, enjoys a larger share (89\%) of sourcing firms, compared with the conservative one $(75 \%)$. 
Last but not least, sampled firms' sourcing strategies appear to be complementary, rather than substitutes to each other. This becomes evident after looking at the average number of modes per firm which is 1.62 under the conservative definition and 1.8 under the liberal one (Table 2). These results are strongly consistent with previous evidence reported in Kohler and Smolka $(2011,2012)$ and point to the benefit of keeping both mutually inclusive and mutually exclusive proxies for empirical purposes.

For the sake of completeness, Figure 2 and Figure 3 extracts mutually inclusive and mutually exclusive sourcing strategies from the data reported in Table 2, to help the reader focus on some relevant facts.

\section{[Insert Figure 2 about here]}

According to the mutually inclusive definition, our respondents' ranking is: DI-DO-FO-FI, from the most (DI) to the least (FI) frequent choice. In particular, $70 \%(93 \%)$ of the sample engage in domestic integration under the conservative (liberal) definition, 42\% (57\%) in domestic outsourcing, $8 \%(12 \%)$ in foreign outsourcing and 3\% (7\%) in foreign integration (Figure 2). The existence of such a ranking and its robustness with respect to the conservative versus liberal perspective suggests that there are some fixed costs associated to the choice of out- rather than inand foreign rather than domestic sourcing. According to our data, highest costs rest with FI, followed by FO, DO and DI. This ranking is in line with the theoretic case of Antras and Helpman $(2004,2008)$ in that foreign operations turn out to be more expensive than domestic ones; however, domestic outsourcing turns out to be more costly than domestic integration for Lombard players, while the opposite is assumed in Antras and Helpman (2004, 2008).

Figure 3 displays mutually exclusive sourcing strategies according to the conservative and the liberal definition.

As mentioned above, moving from mutually inclusive to mutually exclusive sourcing strategies entails some discretion by the author that arbitrarily chooses a unique category to be assigned to firms pursuing mixed designs. A careful inspection at the existing empirical literature suggests three 
possible ways out for this problem. A first solution is due to Tomiura (2007b), where the author simply assigns each firm the exact combination of pure strategies that it implements. In our case, this implies to consider the 15 combinations of DO, DI, FO and FI displayed in Table 2. A second solution is due to Kohler and Smolka (2012) and Federico (2010) that assign each firm the category which is associated to the highest fixed costs, according to Antras and Helpman (2004, 2008)' ranking. This means that, from Table 2, FI survives whatever combination; FO prevails over DO and DI; DI overshadows just DO and DO is considered only as a pure strategy. Last but not least, Kohler and Smolka (2011) assign each firm the least prevalent category in the overall sample, arguing that it is a good proxy for real world, rather than theoretical, fixed costs implied by the different organizational modes. With our data, firms are said to engage in FI when they perform FI with or without any combination of FO, DI and DO; to engage in FO when they perform FO with or without any combination of DO and DI; to engage in DO when they perform DO with or without DI; and to engage in DI when they pursue only domestic integration.

The main advantage of Tomiura (2007b) is that it preserves all the information coming from the data, without any discretional selection by the author. On the contrary, Kohler and Smolka (2011, 2012) and Federico (2010) introduce a good deal of discretion over the author's choice to deliberately ignore some information. However, following Tomiura (2007b) we are likely to produce difficult to interpret results, given that the theory associates each firm to a single strategy. Moreover, considering the size of our dataset, we need to be cautious and limit the number of sourcing dummies to be included in the econometric analysis. Hence, Tomiura (2007b) turns out to be inappropriate for our purposes. At the same time, we resist from the comfortable theoretic solution of Kohler and Smolka (2012) and Federico (2010) since their ranking is likely to bias results if applied to our data. This becomes evident after a quick inspection at Table 2. Indeed, sampled firms tend to select only DO very exceptionally, while they often combine DO with DI; therefore, assuming Antras and Helpman (2004, 2008)' ranking would result in a severe under 
representation of domestic outsourcing. For all these reasons, we follow Kohler and Smolka (2011) that seem to provide the most suitable solution to our case. Results are shown in Figure $3^{13}$.

[Insert Figure 3 about here]

According to the mutually exclusive definition, our respondents' ranking becomes: DO-DI-FO-FI, from the most (DO) to the least (FI) frequent choice. In particular, 47\% (46\%) of the sample engage in domestic outsourcing under the conservative (liberal) definition, 40\% (36\%) in domestic integration, $10 \%(10 \%)$ in foreign outsourcing and 3\% (8\%) in foreign integration (Figure 3). Two facts are worth noting. First, such a ranking is strongly robust to the conservative versus liberal perspective. Second, mutually inclusive and mutually exclusive definitions produce only partially overlapping rankings of the most preferred sourcing strategies. While domestic still prevails over foreign sourcing, out-sourcing occurs more frequently than in-sourcing in the mutually exclusive case.

\section{ECONOMETRIC ANALYSIS}

In this section we explore the relationship between firms' sourcing behaviour and their economic performance through econometric techniques. Our discussion is organized as follows: first we describe the variables and discuss the empirical specifications; then we comment the main estimation results.

\section{Variables and Specification}

The present research aims at estimating sourcing premia with the Italian regional data described in Section 3. According to Bernard and Jensen (1995, 1999)'s methodology, sourcing premia can be defined as the average percentage difference of performance between firms engaged in a given strategy versus the others. To compute these premia, we regress firms' performance on sourcing dummies, controlling for a number of additional variables that may affect performance as well.

Our econometric model is set accordingly. For every performance measure, three equations are estimated, called (1), (2) and (3). 


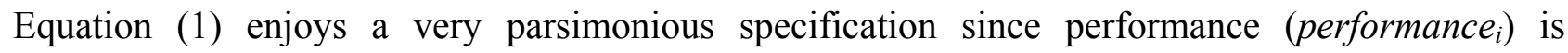

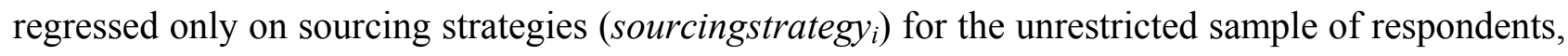
called $\Omega$ unrestr:

$$
\text { performanc } e_{i}=\alpha \text { sourcing strategy }{ }_{i}+\varepsilon_{i} \quad \text { for } i \in \Omega_{-} \text {unrestr }
$$

This basic equation is then completed by firm-level controls ( firmctrl $_{i}$ ), together with industry (industryctrl $)$ and province ( provincectrl $_{i}$ ) fixed effects, as in Equation (2).

(2) performanc $_{i}=\alpha$ sourcing strategy ${ }_{i}+\beta$ firmctrl $_{i}+\gamma$ industryct $_{\text {in }}+\sigma$ provincect $_{i}+\varepsilon_{i}$

$$
\text { for } i \in \Omega_{\text {_unrestr }}
$$

Equation (3) is the same as Equation (2), with the only difference that it is estimated in the restricted sample of the so called "true headquarter firms", called $\Omega_{-}$restr. They are defined as those having less than $50 \%$ of participation by other firms in their joint capital. Identifying the true headquarter firm status is crucial to our study to avoid estimation bias. The theory about global sourcing under contractual incompleteness takes for granted that firms have full discretion over their input procurement choice. However, it might not be the case for real world companies, having more than $50 \%$ of external participation. Under these circumstances, firms are simply likely to follow the sourcing strategies dictated by their parental company, without exerting any discretional choice. Restricting attention to full headquarter firms is thus important to produce consistent results; nonetheless, this comes at the expenses of a lower number of observations. This is the reason why we run regressions both on the unrestricted - with Equations (1) and (2) - and the restricted - with Equation (3) - sample.

$$
\begin{aligned}
& \text { performanc }_{i}=\alpha \text { sourcing strategy }_{i}+\beta \text { firmctrl }_{i}+\gamma \text { industryct }_{i}+\sigma \text { provincect }_{i}+\varepsilon_{i} \\
& \text { for } i \in \Omega_{\text {_restr }}
\end{aligned}
$$

A number of variables are considered in Equations (1), (2) and (3) as a proxy for firms' performance $_{i}$. They range from the number of employees to sales, from value added to profit, from productivity $(T F P)$ to skill intensity, to investigate all potential premia related to sourcing strategies. 
As far as productivity is concerned, we follow Levinsohn and Petrin (2003) estimation method, to deal with simultaneity and selection bias ${ }^{14}$. In particular, we assume the production function of firm $i$, at a given point in time, to be Cobb-Douglas:

$$
Y_{i}=\delta+\omega_{L} L_{i}+\omega_{K} K_{i}+\omega_{M} M_{i}+\omega_{i}+\varepsilon_{i}
$$

where $Y_{i}$ is the logarithm of firm's output, measured by value added; $L_{i}$ and $M_{i}$ are the logarithm of the freely variable inputs labour and intermediate input, approximated respectively by the number of employees and the cost of raw materials; and $K_{i}$ denotes the logarithm of the state variable capital, proxied by total assets. All variables in Equation (4) are deflated by the Producer Price Index for the appropriate two-digit NACE industry.

Independent variables can be distinguished across two main groups, called "core" and "control" regressors. Core regressors denote the main variables of interest, namely sourcing strategy . Several dummies are available, according to the conservative versus liberal definition of mutually inclusive versus mutually exclusive sourcing strategies. To be consistent with the labels defined in Section 4, DO_con_incl, DI_con_incl, FO_con_incl, FI_con_incl are the dummies for DO, DI, FO and FI under the conservative definition of mutually inclusive sourcing strategies; DO_con_excl, DI_con_excl, FO_con_excl, FI_con_excl are the dummies for DO, DI, FO and FI under the conservative definition of mutually exclusive sourcing strategies; DO_lib_incl, DI_lib_incl, FO_lib_incl, FI_lib_incl are the dummies for DO, DI, FO and FI under the liberal definition of mutually inclusive sourcing dummies and DO_lib_excl, DI_lib_excl, FO_lib_excl, FI_lib_excl are the dummies for DO, DI, FO and FI under the liberal definition of mutually exclusive sourcing dummies. Adding to core regressors, Equations (2) and (3) consider a number of "controls" to check robustness of sourcing dummies to the inclusion of firm-, industry- and province-level variables. In particular, firm-level controls include firms' age, group affiliation and export experience; industry fixed effects are measured through sector dummies à la Bell and Pavitt (1993) and province fixed effects are captured by a dummy for Milan, the administrative and economic core of Lombardy. 
OLS estimations are kept throughout the empirical analysis, with the only exception of the skill intensity equation, that follows a Probit model. Under the OLS estimation, sourcing premia can be directly discerned from the $\alpha$ coefficient, capturing the percentage change in performance due to a given sourcing solution ${ }^{15}$; under the Probit estimation, the same is true for marginal effects.

At this stage, it is worth mentioning that survey estimation methods are employed throughout the empirical analysis, to control from the potential bias originating from the response rate. Each combination of a single geographical location (out of four) and a single manufacturing activity (out of four) denotes a stratum (16 in total). In the econometric analysis we use sampling information in order to obtain consistent and efficient estimates and to draw conclusion about Lombardy as a whole. Specifically, we weight each observation by the inverse of the probability of being sampled using, for every stratum, location-industry specific information on the total number of firms in the population and in the sample.

All dependent variables refer to 2009, while regressors date back to 2007. A detailed variable description is available in Table A1, while Table A2 and A3 in Appendix A provide some summary statistics and correlations between firm-level regressors.

\section{Results}

In this section, we comment the main estimation results.

Before moving to the discussion, it is worth emphasizing that our findings should be evaluated with some caution, due to the cross-sectional design of the data described in Section 3. In particular, as many variables are endogenous, one should not interpret regressions as showing the exact direction of causality, but just as a convenient way of summarizing statistical regularities among variables.

Having said this, Table 3 and Table 4 report the empirical evidence about sourcing premia when the conservative definition is applied to mutually inclusive (Table 3) and mutually exclusive (Table 4) sourcing strategies.

In light of the above discussion, for every dependent variable, three specifications are displayed, according to Equations (1), (2) and (3). 
[Insert Table 3 about here]

A first look at Table 3 suggests some interesting facts.

As far as our core variables are concerned, FI_con_incl turns out to be statistically significant, with a positive sign, in every specification. This means that being engaged in foreign integration is associated to better economic performance. Yet, this result is robust to firm-, industry, and province-level controls and it holds both for the unrestricted and the restricted sample of true headquarter firms. Moreover, FI_con_incl is positive and statistically significant irrespective of the various performance measures adopted throughout the empirical analysis. This reveals that FDI makers enjoy a superior performance in terms of sales, number of employees, value added, profit, capital, TFP and skill intensity. Within the group of sourcing dummies, FO_con_incl turns out to be positive and statistically significant as well, but its explanatory power is limited to the sales, value added and profit equations. By and large, our evidence points to the fact that foreign sourcing discloses many advantages to Lombard firms, whether pursued intra or extra firm. On the contrary, we find no effect of domestic sourcing on economic performance, given that DO_con_incl and DI_con_incl never become significant, consistently with previous evidence about internationalization and performance of Italian enterprises, discussed in Section 2. At this stage, it is worth emphasizing also that the magnitude of the FI effect is much larger than the one of other sourcing dummies. Indeed, the coefficient of FI_con_incl is impressively higher than the one FO_con_incl, DO_con_incl and DI_con_incl across all columns of Table 3. Put another way, not only FI discloses a precious performance premium for Lombard enterprises, but this premium is the highest among the existing ones, due to DO, DI and FO. This result is in line with the framework delineated in Kohler and Smolka $(2011,2012)$ and Federico (2010).

As far as our control variables are concerned, only age and group affiliation seem to play some role in shaping firms' performance. Indeed, they are positive drivers of many dependent variables such as sales, number of employees, value added, capital, and skill intensity, confirming previous evidence on Italian enterprises reported in Barba Navaretti et al. (2008), Bugamelli, Cipollone, and 
Infante (2000), Conti, Lo Turco, and Maggioni (2010), Bugamelli and Infante (2003). On the contrary, we find no significant effect of international experience on economic performance, which is quite surprising in light of the empirical literature reviewed in Section 2. Results (not shown) do not change if we replace the export dummy with a dummy capturing import operations or two-way trading. A possible explanation for this puzzling evidence is that Lombard enterprises are so committed to international trade that being an exporter, an importer or both makes no difference since this status applies to the vast majority of players. Alternatively, one might blame data limitations that constraint the analysis and prevent authors from making deeper investigations. Given that our primary interest is on sourcing rather than exporting premia, we believe going deeper into this issue would eventually distort attention from the declared research question. Therefore, we treat export as a mere control and simply document that it seems to play no role in explaining Lombard firms' economic performance.

Table 4 presents our estimation results when the conservative definition of mutually exclusive sourcing strategies is applied.

[Insert Table 4 about here]

To facilitate comparisons with the previous case, we stick to the same specifications as in Table 3. As one may notice, our main findings still hold.

Indeed, among core variables, FI_con_excl turns out to be a positive and significant driver of all performance measures. Yet, this effect is robust to different specifications - including firm, industry and province controls - and to different samples - embracing all respondents or only true headquarter firms. Moreover, $F O \_c o n \_e x c l$ plays some role in enhancing firms' performance too, as in the mutually inclusive case. Notably, being engaged in foreign outsourcing is positively correlated with sales, number of employees and value added, although this result is less robust than before. By and large, moving from the mutually inclusive to the mutually exclusive definition does not alter our main conclusion that, under the conservative perspective: 1) foreign - rather than domestic - sourcing entails remarkable performance premia for firms engaged in FI and FO; 2) 
restricting attention to foreign sourcing, integration - rather than outsourcing - is associated to the highest performance premia for firms engaged in $\mathrm{FI}^{16}$; 3) looking at control variables, age and group are positive and statistically significant in most specifications, while export seems to play no role in explaining Lombard firms' performance.

To complete the picture, Table 5 and Table 6 show our estimation results when the liberal definition is applied to mutually inclusive (Table 5) and mutually exclusive (Table 6) sourcing strategies.

[Insert Table 5 and Table 6 about here]

Compared with the conservative case, the liberal one makes a more restrictive argument, claiming that there exist some sourcing premia, related only to foreign integration. This is because FI_lib_incl is positive and statistically significant in all specifications reported in Table 5, and the same is true for FI_lib_excl in Table 6. On the contrary, foreign outsourcing that plays some role under the conservative definition looks completely disjoint from performance under the liberal one. In fact, FO_lib_incl never proves to be significant in Table 5 and the same applies to FO_lib_excl in Table 6, irrespective of the parsimonious versus rich specification, and of the unrestricted versus restricted sample.

Lastly, control variables perform worse as well: while, in the conservative estimates, age and group are generally positive and significant, in the liberal ones we find only a notable effect of age on firms' size and capital, but this effect vanishes if we restrict attention to true headquarter firms.

To summarize, moving from the mutually inclusive to the mutually exclusive definition does not alter our main conclusion that, under the liberal perspective: 1) foreign - rather than domestic - and in - rather than out - sourcing entails remarkable performance premia for firms engaged in FI; 2) looking at control variables, there is no robust correlation between age, group, export and Lombard firms' performance.

As a further robustness check, Appendix B runs the same estimation exercise as in Tables 3, 4, 5 and 6 on the restricted sample of sourcing enterprises. The underlying idea is to restrict attention to firms that are actually taking some sourcing decisions - both according to the conservative and the 
liberal view - getting rid of those that do not perform the related tasks. Even though we believe this is a proper way of estimating performance premia, it comes at the expenses of a lower number of observations. Given that results are fully consistent with those displayed in Tables 3, 4, 5 and 6 this analysis is moved to Appendix B.

Before coming to the conclusion, a few comments are worth making, based on the evidence reported above.

As a first remark, one should carefully compare results implied by the four definitions of sourcing strategies, to see whether switching from one to the other makes such a difference or not. Recall from Section 4 that our data allow us to measure firms' boundaries through the conservative versus liberal and mutually inclusive versus mutually exclusive perspective. In principle, we apply all four lenses to the data, even though theoretical priors rest only with the conservative definition of mutually exclusive sourcing strategies. A quick inspection at Tables 3, 4, 5 and 6 suggests that there are: a) some results that hold across all definitions (i.e. in all tables); b) some results that hold only for the conservative view, irrespective of the mutually inclusive versus mutually exclusive case (i.e. only in Tables 3 and 4); c) some results that hold only for the liberal view, irrespective of the mutually inclusive versus mutually exclusive case (i.e. only in Tables 5 and 6). Results of type a) regard foreign integration premia that emerge as a robust finding throughout the empirical analysis. Results of type b) involve the role of foreign outsourcing, together with firms' age and group affiliation that matter only under the conservative case. Results of type c) reverse previous findings in that FO, age and group do not play any significant role under the liberal one. Notice that moving from mutually inclusive to mutually exclusive dummies, under the conservative or the liberal view makes no sizeable difference. Hence, what matters is not the way firms are assigned one or more sourcing modes, but the number of tasks along with sourcing modes are computed. This is something that previous studies could not deal with, due to data limitation. On the contrary, having disaggregated firms' production process by task, we have the chance to make a clue on this issue. 
As a second remark, one should confront our empirical findings with the theoretical priors available under the literature on global sourcing under contractual incompleteness and internationalization and performance at the micro level. By and large, our estimates are consistent with both strands. Indeed, we document the existence of robust correlations between integration, foreign exposure and performance. However, looking at firms' ownership and location decisions in a unitary framework, we make a step further and suggest that firms' economic outcome is not just a matter of vertical integration (as postulated by the first strand) or internationalization (as implied by the second one), but it is the joint effect of the make and foreign choices. This is something that previous studies could not analyze, because of data limitation, while our survey design is broad enough to embrace all factors in a coherent setting.

As a third remark, one could ask if our results are in line with previous evidence about Italian enterprises on related issues. In particular, the comparison involves, on the one hand, Federico (2010), dealing with global sourcing of Italian enterprises and, on the other hand, Cusmano, Mancusi, and Morrison (2009, 2010), studying outsourcing strategies of Lombard enterprises. As in Federico (2010), we find that FI is the least prevalent organizational mode and the one associated to the highest premia. Moreover, domestic location overcomes foreign location both for his sample of Italian enterprises and for our sample which is, instead, regionally based. However, if one looks more closely at the relative prevalence of the four sourcing strategies, she realizes that FO and FI namely those implying internationalization - are definitely more widespread in our data than in Federico (2010)'s, meaning that Lombard enterprises tend to be more prone to cross national barriers than the Italian average player ${ }^{17}$. In the end, this means that Lombardy exhibits a higher proportion of firms enjoying performance premia due to FI than the rest of the country, confirming the general wisdom according to which this region is at the core of the Italian economy, as mentioned in Section 3. Lastly, one could view our findings as highly complementary to those reported in Cusmano, Mancusi, and Morrison (2009, 2010) for a different sample of Lombard enterprises. Similarly to those papers, we document that outsourcing is a very common 
phenomenon, involving roughly $50 \%$ of Lombard firms; nonetheless, international outsourcing is still confined to a handful of players, accounting for less than $10 \%$ of the total. Differently from Cusmano, Mancusi, and Morrison (2009), we do not restrict attention to the determinants of domestic and international outsourcing, but rather look at firms' boundaries from a higher resolution perspective that allows firms to vertically integrate as well. This complements previous findings on the correlation between international outsourcing and skill intensity (Cusmano, Mancusi, and Morrison, 2010) or innovation (Cusmano, Mancusi, and Morrison, 2010) letting us detect whether this correlation is a matter of international outsourcing per se (namely a performance premium related to $\mathrm{FO}$ ), a matter of purely international strategy (i.e. a performance premium related to $\mathrm{FO} / \mathrm{FI}$ ), or a matter of purely outsourcing strategy (i.e. a performance premium related to $\mathrm{DO} / \mathrm{FO}$ ). Indeed, the existence of FO premia in terms of sales, number of employees and value added, under our conservative definition, reinforces previous findings about international outsourcing of Lombard enterprises; however, the existence of robust FI premia surviving whatever specification, performance variables, sourcing definition and sample seems to suggest that internationalization plus vertical integration, rather than outsourcing, is key to the Lombard success.

\section{CONCLUSION}

This paper integrates two recent strands of the literature, to estimate sourcing premia with Italian regional data.

Taking advantage of a rich dataset, collected by the author through survey interviews, we develop a richer taxonomy of sourcing strategies and consider a wider array of performance variables, compared with the existing studies on global sourcing under contractual incompleteness. Moreover, we disentangle the relationship between firms' performance and their sourcing behaviour adding ownership to the location dimension already analyzed by the literature on internationalization and performance at the micro level. 
In the end, our main result is that there exist some performance differences among firms taking different sourcing solutions. Indeed, survey estimation methods reveal that foreign rather than domestic and in- rather than out- sourcing entails significant size, value added, capital, productivity, profit and skill intensity premia for Lombard enterprises. This result is robust to different specifications, samples, performance measures and definitions of sourcing strategies. Yet, it steps forward the two strands mentioned above, combining the main insights coming from already existing studies. In fact, we find some robust correlations between integration, foreign exposure and performance: this goes beyond the link between sourcing and productivity - predicted by the literature on global sourcing under contractual incompleteness - and the link between international business and economic outcomes - documented by the literature on internationalization and performance at the micro level. Notably, our contribution is to show that firms' economic outcome is not just a matter of vertical integration or internationalization, but it is the joint effect of the make and foreign choices, since FI is the only sourcing strategy that survives whatever robustness check.

Even though we believe this is quite an interesting finding, we are aware of some data limitations that plague the present analysis and constraint its scope.

First of all, although our sample turns out to be representative of the entire population of Lombard enterprises, it is small in size. This might be a problem when selecting the set of regressors for econometric purposes, since we cannot include too many variables. Relying on a larger database would allow us, for instance, to build sourcing dummies for every task, instead of grouping input manufacturing, R\&D and other services under the same liberal definition. Based on this information, one could compare sourcing premia not only between different organizational modes, but also within the same mode but looking at different tasks along firms' production process.

Adding to size, another major concern regarding our data is their longitudinal nature. Even though we collect performance measures for a five year-period, sourcing strategies and international experience refer only to 2007 . This prevents us from running a proper causality test that panel data would instead allow for. Put another way, while the present study finds robust correlations between 
sourcing and performance, it cannot make any clue on the direction of causality, going from the former to the latter - in the spirit of the learning-by-internationalization argument - or the other way round - according to a self-selection mechanism. Dealing with causality in a proper way is important not only for academic purposes, but also to derive some policy implications. For instance, if evidence supports the self-selection hypothesis, better enterprises self-select into foreign integration. In this case, the policy maker could try to promote local growth to foster internationalization. In fact, helping firms' reach a certain threshold in terms of size, profit, value added, productivity etc., she would make them strong enough to afford the extra cost of operating abroad. On the contrary, if evidence supports the learning-by-internationalization hypothesis, firms become better as a result of their foreign exposure. In this case, the policy maker could instead promote internationalization to enhance local growth because international experience per se would act as a springboard for economic performance. To be quite honest, our data cannot say that much on this regard. In this sense, our study should be considered only as a first step towards the investigation of sourcing premia.

Hopefully, our preliminary evidence will encourage further research on the same topic. From an empirical point of view, one could build on the main drawbacks identified above to construct a larger dataset with panel information. This would help assess the direction of causality in a proper way and provide more rigorous econometric estimates. From a theoretical point of view, one could try, instead, to relax the standard assumptions behind Antras and Helpman (2004, 2008)'s taxonomy and derive some testable predictions for what we called the liberal case. This would result in a more realistic treatment of firms' boundaries, encompassing the multiple tasks performed along real world complex production processes.

We believe both extensions are worth making to provide a deeper characterization of global sourcing and a better understanding of its relationship with firms' performance in a context of heterogeneity. 


\section{FOOTNOTES}

${ }^{1}$ From a terminological point of view, FI can be denoted also as foreign direct investment and FO as international outsourcing or offshoring (Amiti and Wei, 2005).

${ }^{2}$ For a detailed discussion on this issue, see Section 5.

${ }^{3}$ In the literature on global sourcing under contractual incompleteness, firms' boundaries are said to be shaped by ownership and location decisions. This can be rephrased as a matter of geographical and organizational proximity, building on Torre and Rallet (2005). Indeed, geographical proximity expresses the kilometric distance that separates two units in the geographical space, looking like the home versus foreign trade-off. On the contrary, organizational proximity means the ability of an organization to make its members interact with each other in the relational space, resembling the make versus buy trade-off. Under this jargon, sourcing strategies result from the intersection between geographical and organizational proximity for firms that are located in a space, take territories into account but are not defined or limited by them (Torre and Rallet, 2005).

${ }^{4}$ For a survey on this topic, see: Spencer (2005), Antras (2014), Antras and Rossi-Hansberg (2009).

${ }^{5}$ The difference between Antras and Helpman (2004) and Antras and Helpman (2008) lays in the assumptions about contractual incompleteness. Indeed, the 2008 paper allows the degree of contractibility to vary across inputs and countries, which means that contractual incompleteness is treated as a continuous - rather than a binary - variable. This enables the authors to study the effects of a change in the quality of contractual institutions on the relative prevalence of the different sourcing strategies. Thus, an interesting result of the model is that better contracting institutions in the South raise the prevalence of foreign modes, but may reduce the relative prevalence of FI or FO (while it always reduces the relative prevalence of FI in the 2004 framework). This crucially depends on whether the institutional improvement affects disproportionately the contractibility of a particular input controlled by the final good producer or the input supplier. 
${ }^{6}$ For a survey on this topic, see: Lopez (2005), Wagner (2007, 2012), Greenaway and Kneller (2007), Singh (2010), Hayakawa and Machikita (2012).

${ }^{7}$ Notice that this framework is entirely consistent with the assumption of firms' heterogeneity à la Melitz (2003) embedded in Antras and Helpman $(2004,2008)$ models of global sourcing discussed in the previous subsection.

${ }^{8}$ Only a few studies identify performance discounts related to foreign involvement. For instance, Benfratello, Razzolini, and Vannoni (2009) show that more investment in innovation is associated to less offshoring; Bugamelli and Infante (2003) find that average wage has a negative impact on firms' probability to export; age is negatively correlated with production partnerships in Bugamelli, Cipollone, and Infante (2000); productivity is negatively correlated with subcontracting in Razzolini and Vannoni (2011), negatively correlated with export intensity to low income destinations and not correlated with export intensity to high income destinations in Crinò and Epifani (2012).

${ }^{9}$ According to Bell and Pavitt (1993), in "traditional supplier dominated" industries, technical change comes from the supplier of inputs while technology is transferred in the form of capital goods and components. The category includes textile, leather, footwear, home furnishings etc. In "scale intensive" industries - like automotives and chemicals technical change is generated by the design and operation of complex production systems. In "science-based" industries, technology emerges from corporate R\&D and it is heavily dependent on academic research. In "specialised supplier dominated" industries, firms provide high performance equipments in the form of components, instruments or software to advanced users.

${ }^{10}$ For a discussion about the authors' choice, vis-à-vis with some alternative approaches, see the following subsection.

${ }^{11}$ In this context, we define "pure" strategies DO, DI, FO and FI, while "mixed" strategies denote a combination of them. These labels are used only for expositional convenience and should not be confused with the game theoretic ones.

${ }^{12}$ These results are also consistent with Cusmano, Mancusi, and Morrison $(2009,2010)$ in that international outsourcing is quite rare, although domestic outsourcing features prominently among Lombard firms' sourcing modes.

${ }^{13}$ In principle, our data would allow for another solution. Recall that sampled firms are asked to specify whether they perform a given task or not and in which percentage of the total. Hence, to move from mutually inclusive to mutually exclusive sourcing strategies, one could simply assign each firm the mode characterized by the highest percentage, meaning that it is the most important way of performing that specific task. However, unreported statistics reveal that most frequent strategies - like DI and DO - are systematically associated to the highest shares, while least frequent strategies - like FO and FI - are associated to the lowest shares. Therefore, adopting this kind of solution would result in a severe underestimation of FO and FI.

${ }^{14} \mathrm{~A}$ key issue in the estimation of the production function is the correlation between unobservable productivity shocks and input levels. Indeed, profit-maximizing firms respond to positive (negative) shocks by expanding (reducing) output, 
which requires more (less) inputs. To deal with simultaneity and selection biases in this context, Levinsohn and Petrin (2003) introduce an estimator that uses intermediate inputs as a proxy for unobservable productivity shocks. An alternative approach, due to Olley and Pakes (1996), employs investment as a proxy for unobservable productivity shocks. For a discussion about the benefits Levinsohn and Petrin methodology see Petrin, Poi, and Levinsohn (2004).

${ }^{15}$ Since the TFP equation is set as to regress the $\ln$ of TFP on sourcing dummies and control variables, in that case, premia must be calculated with the formula $100\left(\mathrm{e}^{\alpha}-1\right)$, due to Bernard and Jensen $(1995,1999)$.

${ }^{16}$ This evidence is in line with the theoretical framework à la Antras and Helpman $(2004,2008)$ and with previous empirical studies due to Kohler and Smolka (2011, 2012), Federico (2010) and Tomiura (2007b). However, while the above mentioned papers only deal with productivity, our results are more general in that a number of performance measures are considered as a proxy for firms' performance.

${ }^{17}$ This result sounds even more striking if one considers that Federico (2010)'s sample is drawn from $7^{\text {th }}$ wave of the Capitalia "Survey on Manufacturing Enterprises", which is well known for being unbalanced in favour of medium and large enterprises. 


\section{REFERENCES}

Amiti, Mary and Shang J. Wei. 2006. "Service Offshoring and Productivity: Evidence from the United States”, Working Papers No. 11926, National Bureau of Economic Research.

Antras, Pol. 2003. "Firms, Contracts, and Trade Structure", Quarterly Journal of Economics, 118(4), 1375-1418.

Antras, Pol and Elhanan Helpman. 2004. "Global Sourcing”, Journal of Political Economy, 112(3), 552-580.

Antras, Pol and Elhanan Helpman. 2008. "Contractual Frictions and Global Sourcing”, in E. Helpman, D. Marin, and T. Verdier (eds.), The Organization of Firms in a Global Economy. Cambridge: Harvard University Press, pp. 9-54.

Antras, Pol and Esteban Rossi-Hansberg. 2009. "Organizations and Trade", Annual Review of Economics, 1(1), 43-64.

Antras, Pol. 2014. "Grossman -Hart (1986) Goes Global: Incomplete Contracts, Property Rights, and the International Organization of Production", Journal of Law, Economics, and Organization, in press, DOI:10.1093/jleo/ews023

ASR (2013) Annuario Statistico Regionale Lombardia. Milan: Arti Grafiche Colombo.

Barba Navaretti, Giorgio, Roberto Basile, Luigi Benfratello, Davide Castellani, Silvia Cerisola and Angelica Salvi. 2008. "Le imprese e il mercato internazionale: quali prospettive per il Mezzogiorno italiano?”, Luca D'Agliano Policy Report. Milan: Centro Studi Luca D’Agliano.

Barba Navaretti, Giorgio, Matteo Bugamelli, Fabiano Schivardi, Carlo Altomonte, Daniel Horgos and Daniela Maggioni. 2011. "The Global Operations of European Firms", Second EFIFE Policy Report, Bruegel, No.12.

Basile, Roberto. 2001. "Export Behaviour of Italian Manufacturing Firms over the Nineties: The Role of Innovation", Research Policy, 30(8), pp. 1185-1201.

Basile, Roberto, Anna Giunta and Jeffrey B. Nugent. 2003. "Foreign Expansion by Italian Manufacturing Firms in the Nineties: an Ordered Probit Analysis", Review of Industrial Organization, 23(1), 1-24.

Bell, Martin and Keith Pavitt. 1993. "Accumulating Technological Capability in Developing Countries”, World Bank Economic Review, Supplement, 257-281.

Benfratello, Luigi and Tiziano Razzolini. 2009. "Firms' Productivity and Internationalisation Choices: Evidence from a Large Sample of Italian Firms", in L. Piscitello and G. Santangelo (eds.), Multinationals and Local Competitiveness. Milano: Franco Angeli.

Benfratello, Luigi, Tiziano Razzolini, and Alessandro Sembenelli. 2009. "Does ICT Investment Spur or Hamper Offshoring? Empirical Evidence from Microdata", Working Paper No. 5, Department of Economics and Public Finance "G. Prato", University of Torino.

Bernard, Andrew B. and Bradford J. Jensen. 1995. "Exporters, Jobs and Wages in US manufacturing: 1976-1987”, Brookings Papers on Economic Activity, Microeconomics, pp. 67-119. 
Bernard, Andrew B. and Bradford J. Jensen. 1999. "Exceptional exporter performance: cause, effect, or both?", Journal of International Economics, 47(1),1-25.

Bernard, Andrew B. and Bradford J. Jensen, Stephen J. Redding, and Peter K. Schott. 2010. "Intrafirm Trade and Product Contractibility", American Economic Review (Papers \& Proceedings), 100(2): 444-448

Bratti, Mssimiliano and Giulia Felice. 2012. "Are Exporters more Likely to Introduce Product Innovation?", The World Economy, 35(11),1559-1598.

Bugamelli, Matteo, Piero Cipollone, and Luigi Infante. 2000. L'internazionalizzazione delle imprese italiane negli anni novanta, Rivista Italiana degli Economisti, 3(1), 349-386.

Bugamelli, Matteo and Luigi Infante. 2003. "Sunk Costs to Exports", Bank of Italy Research Papers No. 469, Bank of Italy.

Casaburi, Lorenzo, Valeria Gattai, and Gaetano A. Minerva. 2007. 'Firms' International Status and Heterogeneity in Performance: Evidence From Italy", Rivista di Politica Economica, special issue May-June, 151-187.

Castellani, Davide. 2007. "L'internazionalizzazione della produzione in Italia: caratteristiche delle imprese ed effetti sul sistema economico", L'Industria, 28(3), 467-493.

Castellani, Davide and Antonello Zanfei. 2007. "Internationalisation, Innovation and Productivity: How Do Firms Differ in Italy?", The World Economy, 30(1), 156-176.

Castellani, Davide and Giorgia Giovannetti. 2010. "Productivity and the International Firm: Dissecting Heterogeneity", Journal of Economic Policy Reform, 13(1), 25-42.

Castellani, Davide, Francesco Serti, and Chiara Tomasi. 2010. "Firms in International Trade: Importers and Exporters Heterogeneity in the Italian Manufacturing Industry" The World Economy, $33(3), 424-457$.

Conti, Giuliano, Alessia Lo Turco, and Daniela Maggioni. 2010. "Exporters in Services: New Evidence from Italian Firms", Applied Economic Quarterly, 56(1), 73-98.

Corcos, Gregory, Delphine M. Irac, Giordano Mion, and Thierry Verdier. 2013. "The Determinants of Intrafirm Trade: Evidence from French Firms", Review of Economics and Statistics, 95(3), 825838.

Corò, Giancarlo and Roberto Grandinetti, 1999. "Strategie di delocalizzazione e processi evolutivi nei distretti industriali italiani”, L'Industria, 4(4), 897-924.

Crinò, Rosario and Paolo Epifani. 2012. "Productivity, Quality and Export Behaviour", The Economic Journal, 122 (565), 1206-1243.

Cusmano, Lucia and Franco Malerba. 2005. "Le sfide strategiche per l'innovazione in Lombardia", in IRER (Istituto Regionale di Ricerca), "Società, governo e sviluppo del sistema Lombardo: dieci anni di esperienze", Milan: Guerini e Associati, pp.151-154. 
Cusmano, Lucia, Maria L. Mancusi, and Andrea Morrison. 2009. "Innovation and the Geographical Organisational Dimension of Outsourcing: Evidence from Italian Firm-Level Data", Structural Change and Economic Dynamics, 20(3), 183-195.

Cusmano, Lucia, Maria L. Mancusi, and Andrea Morrison. 2010. "Globalization of Production and Innovation: How Outsourcing is Reshaping an Advanced Manufacturing Area", Regional Studies, 44(3), 235-252.

Defever, Fabrice and Farid Toubal. 2013. "Productivity, Relationship-Specific Inputs and the Sourcing Modes of Multinationals", Journal of Economic Behaviour \& Organization, 94(C), 245357.

Federico, Stefano. 2010. "Outsourcing versus Integration at Home or Abroad and Firm Heterogeneity", Empirica, 37(1), 47-63.

Federico, Stefano. 2012. "Headquarter Intensity and the Choice between Outsourcing versus Integration at Home or Abroad", Industrial and Corporate Change, 21(6), 1337-1358.

Feenstra, Robert C. 1998. "Integration of Trade and Disintegration of Production in the Global Economy", Journal of Economic Perspective, 12(4), 31-50.

Ferragina, Anna M. and Beniamino. 2001. "Caratteristiche delle imprese esportatrici italiane", in B. Quintieri (ed.), Le imprese esportatrici italiane: caratteristiche, performance $e$ internazionalizzazione. Bologna: Il Mulino.

Helpman, Elhanan. 2006. "Trade, FDI and the Organization of Firms", Journal of Economic Literature, 44(3), 589-630.

Garofoli, Gioacchino. 1983. "Industrializzazione diffusa in Lombardia”. Milan: Franco Angeli.

Garofoli, Gioacchino. 2002. "Local Development in Europe: Theoretical Models and International Comparisons", European Urban and Regional Studies, 9(3), 225-239.

Giovannetti, Giorgia, Giorgio Ricciuti, and Margherita Vilucchi. 2009. "Size, Innovation and Internationalization: a Survival Analysis of Italian Firms", Applied Economics, 1(1), 1-10.

Greenaway, Davide and Richard A Kneller. 2007. "Firm Heterogeneity, Exporting and Foreign Direct Investment: a Survey”, Economic Journal, 117(February), F134-F161.

Grossman, Sanford J. and Oliver D. Hart. 1986. "The Costs and Benefits of Ownership: a Theory of Vertical and Lateral Integration”, Journal of Political Economy, 94(4), 691-719.

Grossman, Sanford J. and Elhanan Helpman. 2002. "Integration versus Outsourcing in Industry Equilibrium”, Quarterly Journal of Economics, 117(1), 85-120.

Grossman, Sanford J. and Elhanan Helpman. 2003. "Outsourcing vs FDI in Industry Equilibrium", Journal of the European Economic Association, 1(1), 317-327.

Grossman, Sanford J. and Elhanan Helpman. 2005. "Outsourcing in a Global Economy", Review of Economic Studies, 72(1), 135-159. 
Grout, Paul A. 1984. "Investment and Wages in the Absence of Binding Contracts: a Nash Bargaining Approach", Econometrica, 52(2), 449-460.

Hart, Oliver D. and John Moore. 1990. "Property Rights \& the Nature of the Firms", Journal of Political Economy, 98(6), 1119-1158.

Hayakawa, Kazunobu and Tomohiro Machikita. 2012. "Globalization and Productivity: a Survey of Firm-Level Analysis”, Journal of Economic Surveys, 26(2), 332-350.

ISGEP. 2008. "Understanding Cross-Country Differences in Exporter Premia: Comparable Evidence fro 14 Countries”, Review of World Economics, 144(4), 596-635.

ISTAT. 2001. "Ottavo censimento generale dell'industria e dei servizi”. Rome: ISTAT (Italian National Institute of Statistics), Rome.

Ito, Banri, Eiichi Tomiura, and Ryuhei Wakasugi. 2011. "Offshore Outsourcing and Productivity: Evidence from Japanese Firm-Level Data Disaggregated by Task", Review of International Economics, 19(3), 555-567.

Kohler, Wilhelm K. and Marcel Smolka. 2011. "Sourcing Premia with Incomplete Contracts: Theory and Evidence", The B.E. Journal of Economics Analysis and Policy, 11 (1), 1-39.

Kohler, Wilhelm K. and Marcel Smolka. 2012. Global Sourcing Decisions and Firm Productivity: Evidence from Spain”, in R. M. Stern (ed.), Quantitative Analysis of Newly Evolving Patterns of International Trade: Fragmentation; Offshoring of Activities; and Vertical Intra-Industry Trade. Singapore: World Scientific Studies in International Economics 18, World Scientific Publishing, pp. 139-190.

Levinsohn, James and Amin Petrin. 2003. "Estimating Production Functions Using Inputs to Control for Unobservables", Review of Economic Studies, 70(2), 317-342.

Lopez, Ricardo A. 2005. "Trade and Growth: Reconciling the Macroeconomic and Microeconomic Evidence", Journal of Economic Surveys, 19 (4), 623-648.

Mayer, Thierry and Gianmarco I. P. Ottaviano. 2007. The happy few: new facts on the internationalisation of European firms, Bruegel-CEPR EFIM2007 Report, Bruegel Blueprint Series.

McLaren, John. 2000. "Globalisation and Vertical Structure", American Economic Review, 90(5), 1239-1254.

Melitz, Marc J. 2003. "The impact of Trade on Intra-Industry Reallocations and Aggregate Industry Productivity”, Econometrica, 71(6), 1661-1694.

Nunn, Nathan and Daniel Trefler. 2008. "The Boundaries of the Multinational Firm: An Empirical Analysis", in E. Helpman, D. Marin, and T. Verdier (eds.) The Organization of Firms in a Global Economy. Cambridge: Harvard University Press, pp. 55-83.

Olley, Stephen G. and Ariel Pakes. 1996. "The Dynamics of Productivity in the Telecommunications Equipment Industry”, Econometrica, 64(6), 1263-1297.

Ottaviano, Gianmarco I. P. and Alessandro Turrini .2007. "Distance and FDI when Contracts are Incomplete”, Journal of the European Economic Association, 5(4), 796-822. 
Petrin, Amil, Brian P. Poi, and James Levinsohn. 2004. "Production Function Estimation in Stata Using Inputs to Control for Unobservables", The Stata Journal, 4(2), pp. 113-123.

Razzolini, Tiziano and Davide Vannoni. 2011. "Export Premia and Sub-contracting Discount Passive Strategies and Performance in Domestic and Foreign Markets", The World Economy, 34(6), 984-1013.

Serti, Francesco and Chiara Tomasi. 2008a. "Self-Selection and Post-Entry Effects of Exports: Evidence from Italian Manufacturing Firms", Review of World Economics, 144(4), pp.660-694.

Serti, Francesco and Chiara Tomasi. 2008b. "Firm Heterogeneity: Do Destinations of Exports and Origins of Imports Matter?", in L. Piscitello and G. Santangelo (eds.), Multinationals and local competitiveness. Milano: Franco Angeli.

Serti, Francesco and Chiara Tomasi. 2012. "Self-Selection along Different Export and Import Markets", Economics Letters, 117(1), 102-105.

Serti, Francesco, Chiara Tomasi, and Antonello Zanfei. 2010. "Who Trades with Whom? Exploring the Links between Firm's International Activities, Skills and Wages", Review of International Economics, 18(5), 951-971.

Singh, Tarlok. 2010. "Does International Trade Cause Economic Growth? A Survey", The World Economy, 33(11), 1517-1564.

Spencer, Barbara J. 2005. "International Outsourcing and Incomplete Contracts", Canadian Journal of Economics, 2005, 38(4), 1107-1135.

Tomiura, Eiichi. 2005. "Foreign Outsourcing and Firm-Level Characteristics: Evidence from Japanese Manufacturers", Journal of the Japanese and International Economies, 19(2), 255-271.

Tomiura, Eiichi. 2007a. "Foreign Outsourcing, Exporting, and FDI: A Productivity Comparison at the Firm-Level”, Journal of International Economics, 72(1), 113-127.

Tomiura, Eiichi. 2007b. "Global Sourcing, Technology, and Factor Intensity: Firm-Level Relationships”, RIETI Discussion Paper Series No. 24.

Tomiura, Eiichi. 2009. "Foreign versus Domestic Outsourcing: Firm-Level Evidence on the Role of Technology", International Review of Economics and Finance, 18(2), 219-226.

Torre, Andre and Alain Rallet. 2005. "Proximity and Localization", Regional Studies, 39(1), 47-59.

Wagner, Joachim. 2007. "Exports and Productivity: A Survey of the Evidence from Firm-Level Data", The World Economy, 30(1), 60-72.

Wagner, Joachim. 2012. "International Trade and Firm Performance: A Survey of Empirical Studies since 2006", Review of World Economics, 148(2), 235-267.

Yeaple, Stephen R. 2006. "Offshoring, Foreign Direct Investment, and the Structure of U.S. Trade", Journal of the European Economic Association (Papers and Proceedings), 4(2-3), 602-611.

Zeile, William J. 1997. "US Intrafirm Trade in Goods”, Survey of Current Business, 77(2), 23-38. 


\section{APPENDIX A}

This appendix provides some variables description (Table A1), together with the summary statistics (Table A2) and correlation matrix (Table A3) of firm-level regressors.

[Insert Table A1, A2, A3 about here] 


\section{APPENDIX B}

This appendix shows estimation results for the restricted sample of sourcing firms. Table B1 runs the same econometric exercise as the one reported in Table 3; Table B2 should be confronted with Table 4; Table B3 with Table 5; Table B4 with Table 6. The only difference compared with Table 4 and 6 is that we cannot include all sourcing dummies under the mutually exclusive definition. This is because, excluding NS firms, DO, DI, FO and FI become perfectly collinear. Our choice is then to have domestic integration as the excluded category, given that it is the one associated to the lowest fixed cost in our sample.

[Insert Table B1, B2, B3, B4 about here] 


\section{TABLES}

TABLE 1: Sample versus population of Lombard enterprises, by geographical location, manufacturing activity and firm size

\begin{tabular}{|lrrrr|}
\hline & \multicolumn{2}{c}{ sample } & \multicolumn{2}{c|}{ population } \\
& no. firms & $\%$ & no. firms & $\%$ \\
\hline & & & & \\
Geographical & & & & \\
North-West & 61 & $26.75 \%$ & 17400 & $20.54 \%$ \\
North-East & 69 & $30.26 \%$ & 24695 & $29.15 \%$ \\
South-West & 83 & $36.40 \%$ & 36064 & $42.57 \%$ \\
South-East & 15 & $6.58 \%$ & 6553 & $7.74 \%$ \\
& & & & \\
Manufacturing activity & & & & \\
supplier dominated & 74 & $32.46 \%$ & 26607 & $31.41 \%$ \\
specialized supplier dominated & 37 & $16.23 \%$ & 16006 & $18.89 \%$ \\
science based & 11 & $4.82 \%$ & 4664 & $5.51 \%$ \\
scale intensive & 106 & $46.49 \%$ & 37435 & $44.19 \%$ \\
& & & & \\
Firm size & & & & \\
$<50$ & 217 & $94.90 \%$ & 81667 & $96.41 \%$ \\
$50-249$ & 9 & $4.14 \%$ & 2667 & $3.15 \%$ \\
$>249$ & 2 & $0.96 \%$ & 378 & $0.45 \%$ \\
tot. manufacturing & & & & \\
& 228 & $100.00 \%$ & 84712 & $100.00 \%$ \\
\hline
\end{tabular}

TABLE 2: Sampled firms' sourcing strategies, conservative versus liberal definition

\begin{tabular}{|lll|}
\hline sourcing strategy & conservative definition & liberal \\
\hline DI & 69 & 78 \\
DO & 8 & 1 \\
FI & 1 & 1 \\
FO & 1 & 0 \\
DIDO & 72 & 98 \\
DIFI & 1 & 3 \\
DIFO & 5 & 2 \\
DOFI & 0 & 0 \\
DOFO & 3 & 0 \\
FIFO & 0 & 0 \\
DIDOFI & 3 & 7 \\
DIDOFO & 8 & 19 \\
DIFIFO & 0 & 0 \\
DOFIFO & 0 & 0 \\
DIDOFIFO & 1 & 6 \\
NS & 56 & 13 \\
total number of sourcing firms & 172 & 215 \\
average number of sourcing strategies & 1.62 & 1.8 \\
total number of firms in the sample & 228 & 228 \\
\hline & & \\
\hline
\end{tabular}


TABLE 3: Estimation results under the conservative definition of mutually inclusive sourcing strategies, NS included

\begin{tabular}{|c|c|c|c|c|c|c|c|c|c|c|c|c|c|c|c|c|c|c|c|c|c|}
\hline & \multicolumn{3}{|c|}{ employees } & \multicolumn{3}{|c|}{ sales } & \multicolumn{3}{|c|}{ value added } & \multicolumn{3}{|c|}{ profit } & \multicolumn{3}{|c|}{ capital } & \multicolumn{3}{|c|}{ TFP } & \multicolumn{3}{|c|}{ skill intensity } \\
\hline & (1) & $\begin{array}{l}\text {-S estimate } \\
\text { (2) }\end{array}$ & tes & (1) $\mathrm{O}$ & $\begin{array}{l}\text { LS estimate } \\
\text { (2) }\end{array}$ & es & (1) $\mathrm{O}$ & $\begin{array}{l}\text { LS estimat } \\
\text { (2) }\end{array}$ & tes & (1) $\mathrm{Ol}$ & $\begin{array}{l}\text { LS estima } \\
\text { (2) }\end{array}$ & (3) & (1) 0 & $\begin{array}{l}\text { LS estimate } \\
\text { (2) }\end{array}$ & (3) & (1) OL & $\begin{array}{l}\text { S estima } \\
\text { (2) }\end{array}$ & tes & & $\begin{array}{l}\text { bit estima } \\
\text { (2) }\end{array}$ & (3) \\
\hline DO_con_incl & $\begin{array}{l}-12.27 \\
(.172)\end{array}$ & $\begin{array}{l}-7.186 \\
(.366)\end{array}$ & $\begin{array}{l}-5.913 \\
(.454)\end{array}$ & $\begin{array}{c}-1893.374 \\
(.353)\end{array}$ & $\begin{array}{c}-1454.379 \\
(.433)\end{array}$ & $\begin{array}{c}-1164.663 \\
(.528)\end{array}$ & $\begin{array}{c}-641.910 \\
(.414)\end{array}$ & $\begin{array}{c}-492.750 \\
(.490)\end{array}$ & $\begin{array}{c}-472.485 \\
(.510)\end{array}$ & $\begin{array}{l}34.299 \\
(.841)\end{array}$ & $\begin{array}{l}60.912 \\
(.729)\end{array}$ & $\begin{array}{l}22.124 \\
(.900)\end{array}$ & $\begin{array}{c}-957591.7 \\
(.185)\end{array}$ & $\begin{array}{c}-865504.7 \\
(.156)\end{array}$ & $\begin{array}{c}-799017.5 \\
(.187)\end{array}$ & $\begin{array}{l}-0.022 \\
(.867)\end{array}$ & $\begin{array}{l}-0.089 \\
(.572)\end{array}$ & $\begin{array}{l}-0.083 \\
(.604)\end{array}$ & $\begin{array}{l}-0.056 \\
(.528)\end{array}$ & $\begin{array}{l}-0.014 \\
(.881)\end{array}$ & $\begin{array}{l}-0.016 \\
(.861)\end{array}$ \\
\hline DI_con_incl & $\begin{array}{c}12.582 \\
(.141)\end{array}$ & $\begin{array}{l}8.721 \\
(.172)\end{array}$ & $\begin{array}{l}7.862 \\
(.202)\end{array}$ & $\begin{array}{c}138.774 \\
(.947)\end{array}$ & $\begin{array}{c}-620.612 \\
(.726)\end{array}$ & $\begin{array}{c}-763.947 \\
(.657)\end{array}$ & $\begin{array}{l}597.270 \\
(.434)\end{array}$ & $\begin{array}{c}255.415 \\
(.679)\end{array}$ & $\begin{array}{c}355.031 \\
(.540)\end{array}$ & $\begin{array}{l}-7.331 \\
(.973)\end{array}$ & $\begin{array}{l}-84.918 \\
(.669)\end{array}$ & $\begin{array}{l}-2.257 \\
(.990)\end{array}$ & $\begin{array}{c}931113.9 \\
(.182)\end{array}$ & $\begin{array}{c}723257 \\
(.213)\end{array}$ & $\begin{array}{c}744606.6 \\
(.171)\end{array}$ & $\begin{array}{l}0.111 \\
(.357)\end{array}$ & $\begin{array}{l}0.147 \\
(.210)\end{array}$ & $\begin{array}{l}0.142 \\
(.230)\end{array}$ & $\begin{array}{l}-0.083 \\
(.371)\end{array}$ & $\begin{array}{l}-0.101 \\
(.280)\end{array}$ & $\begin{array}{l}-0.096 \\
(.305)\end{array}$ \\
\hline FO_con_incl & $\begin{array}{c}12.136 \\
.134)\end{array}$ & $\begin{array}{l}11.015 \\
(.374)\end{array}$ & $\begin{array}{l}9.507 \\
(.434)\end{array}$ & $\begin{array}{c}7383.892 \\
(.014)^{\star \star}\end{array}$ & $\begin{array}{c}7302.119 \\
(.053)^{\star}\end{array}$ & $\begin{array}{c}7239.236 \\
(.051)^{\star}\end{array}$ & $\begin{array}{c}2463.172 \\
(.020)^{\star \star}\end{array}$ & $\begin{array}{c}2481.405 \\
(.063)^{\star}\end{array}$ & $\begin{array}{c}2540.596 \\
(.054)^{\star}\end{array}$ & $\begin{array}{l}885.081 \\
(.051)^{*}\end{array}$ & $\begin{array}{l}755.777 \\
(.055)^{\star}\end{array}$ & $\begin{array}{c}821.861 \\
(.061)^{\star}\end{array}$ & $\begin{array}{c}1618867 \\
(.143)\end{array}$ & $\begin{array}{c}1697433 \\
(.158)\end{array}$ & $\begin{array}{c}1771352 \\
(.129)\end{array}$ & $\begin{array}{l}0.181 \\
(.554)\end{array}$ & $\begin{array}{l}0.235 \\
(.399)\end{array}$ & $\begin{array}{l}0.223 \\
(.427)\end{array}$ & $\begin{array}{l}0.007 \\
(.965)\end{array}$ & $\begin{array}{l}-0.077 \\
(.613)\end{array}$ & $\begin{array}{l}-0.071 \\
(.637)\end{array}$ \\
\hline FI_con_incl & $\begin{array}{l}323.880 \\
(.000)^{\star \star \star *}\end{array}$ & $\begin{array}{l}284.160 \\
(.003)^{\star \star \star}\end{array}$ & $\begin{array}{l}288.749 \\
(.003)^{\star \star \star}\end{array}$ & $\begin{array}{c}355855.2 \\
(.023)^{\star \star \star}\end{array}$ & $\begin{array}{l}348628 \\
(.030)^{\star \star}\end{array}$ & $\begin{array}{c}349808.5 \\
(.030)^{\star \star}\end{array}$ & $\begin{array}{c}171683.9 \\
(.040)^{\star \star}\end{array}$ & $\begin{array}{l}169151 \\
(.048)^{\star \star}\end{array}$ & $\begin{array}{c}169651.6 \\
(.048)^{\star \star}\end{array}$ & $\begin{array}{c}37328.13 \\
(.039)^{\star \star}\end{array}$ & $\begin{array}{c}37313.57 \\
(.045)^{\star \star}\end{array}$ & $\begin{array}{c}37404.68 \\
(.044)^{\star \star}\end{array}$ & $\begin{array}{l}4.79 \mathrm{e}+07 \\
(.001)^{\star \star \star}\end{array}$ & $\begin{array}{l}4.57 \mathrm{e}+07 \\
(.005)^{\star \star \star}\end{array}$ & $\begin{array}{l}4.63 e+07 \\
(.004)^{\star \star \star}\end{array}$ & $\begin{array}{c}1.462 \\
(.000)^{\star \star \star}\end{array}$ & $\begin{array}{c}1.185 \\
(.000)^{\star \star \star \star}\end{array}$ & $\begin{array}{c}-0.026 \\
(.005)^{\star \star \star}\end{array}$ & $\begin{array}{c}0.626 \\
(.000)^{\star \star \star}\end{array}$ & $\begin{array}{c}0.630 \\
(.002)^{\star \star \star}\end{array}$ & $\begin{array}{c}0.439 \\
(.003)^{\star \star \star}\end{array}$ \\
\hline age & & $\begin{array}{c}0.858 \\
(.029)^{\star \star}\end{array}$ & $\begin{array}{c}0.801 \\
(.044)^{\star \star}\end{array}$ & & $\begin{array}{l}181.873 \\
(.040)^{\star \star}\end{array}$ & $\begin{array}{c}163.749 \\
(.066)^{\star}\end{array}$ & & $\begin{array}{l}67.387 \\
(.061)^{\star}\end{array}$ & $\begin{array}{l}55.416 \\
(.115)\end{array}$ & & $\begin{array}{l}9.724 \\
(.145)\end{array}$ & $\begin{array}{l}5.629 \\
(.274)\end{array}$ & & $\begin{array}{c}60564.36 \\
(.022)^{\star \star}\end{array}$ & $\begin{array}{c}47765.38 \\
(.061)^{\star}\end{array}$ & & $\begin{array}{l}-0.003 \\
(.272)\end{array}$ & $\begin{array}{l}-0.003 \\
(.293)\end{array}$ & & $\begin{array}{l}0.003 \\
(.097)^{\star}\end{array}$ & $\begin{array}{l}0.003 \\
(.098)^{\star}\end{array}$ \\
\hline export & & $\begin{array}{l}-6.089 \\
(.549)\end{array}$ & $\begin{array}{l}-6.494 \\
(.525)\end{array}$ & & $\begin{array}{l}-0.475 \\
(.680)\end{array}$ & $\begin{array}{c}-72.439 \\
(.975)\end{array}$ & & $\begin{array}{c}-230.306 \\
(.797)\end{array}$ & $\begin{array}{c}-210.253 \\
(.817)\end{array}$ & & $\begin{array}{c}215.131 \\
(.235)\end{array}$ & $\begin{array}{c}237.234 \\
(.189)\end{array}$ & & $\begin{array}{c}-245139 \\
(.745)\end{array}$ & $\begin{array}{c}-243922.5 \\
(.750)\end{array}$ & & $\begin{array}{l}-0.016 \\
(.921)\end{array}$ & $\begin{array}{l}-0.018 \\
(.911)\end{array}$ & & $\begin{array}{l}0.113 \\
(.244)\end{array}$ & $\begin{array}{l}0.112 \\
(.244)\end{array}$ \\
\hline group & & $\begin{array}{c}31.941 \\
(.006)^{\star \star \star}\end{array}$ & $\begin{array}{l}25.775 \\
(.018)^{\star \star *}\end{array}$ & & $\begin{array}{l}8465.571 \\
(.007)^{\star \star \star}\end{array}$ & $\begin{array}{c}6893.572 \\
(.016)^{\star \star}\end{array}$ & & $\begin{array}{c}2498.041 \\
(.013)^{\star \star}\end{array}$ & $\begin{array}{c}1870.149 \\
(.028)^{\star \star}\end{array}$ & & $\begin{array}{c}-141.505 \\
(.727)\end{array}$ & $\begin{array}{c}-255.827 \\
(.499)\end{array}$ & & $\begin{array}{l}2131677 \\
(.026)^{\star \star}\end{array}$ & $\begin{array}{c}1365226 \\
(.067)^{\star}\end{array}$ & & $\begin{array}{l}-0.087 \\
(.431)\end{array}$ & $\begin{array}{l}-0.102 \\
(.370)\end{array}$ & & $\begin{array}{l}0.145 \\
(.300)\end{array}$ & $\begin{array}{l}0.150 \\
(.294)\end{array}$ \\
\hline $\begin{array}{l}\text { province } \\
\text { industry }\end{array}$ & & $\begin{array}{l}\text { yes } \\
\text { yes }\end{array}$ & $\begin{array}{l}\text { yes } \\
\text { yes }\end{array}$ & & $\begin{array}{l}\text { yes } \\
\text { yes }\end{array}$ & $\begin{array}{l}\text { yes } \\
\text { yes }\end{array}$ & & $\begin{array}{l}\text { yes } \\
\text { yes }\end{array}$ & $\begin{array}{l}\text { yes } \\
\text { yes }\end{array}$ & & $\begin{array}{l}\text { yes } \\
\text { yes }\end{array}$ & $\begin{array}{l}\text { yes } \\
\text { yes }\end{array}$ & & $\begin{array}{l}\text { yes } \\
\text { yes }\end{array}$ & $\begin{array}{l}\text { yes } \\
\text { yes }\end{array}$ & & $\begin{array}{l}\text { yes } \\
\text { yes }\end{array}$ & $\begin{array}{l}\text { yes } \\
\text { yes }\end{array}$ & & $\begin{array}{l}\text { yes } \\
\text { yes }\end{array}$ & $\begin{array}{l}\text { yes } \\
\text { yes }\end{array}$ \\
\hline obs & 185 & 185 & 179 & 197 & 197 & 191 & 197 & 197 & 191 & 197 & 197 & 191 & 197 & 197 & 191 & 171 & 171 & 162 & 223 & 223 & 214 \\
\hline R2 & .021 & .145 & .134 & .245 & .304 & .314 & . 322 & .372 & 390 & .246 & .264 & .311 & .076 & .164 & 187 & .056 & .112 & .119 & .024 & . 081 & .089 \\
\hline
\end{tabular}

*** means significant at $1 \%, * *$ at $5 \%, *$ at $10 \%$. Coeffecients and p-values (in parenthesis) are shown. In the skill intensity equation, marginal effects are shown instead of coefficients. 
TABLE 4: Estimation results under the conservative definition of mutually exclusive sourcing strategies, NS included

\begin{tabular}{|c|c|c|c|c|c|c|c|c|c|c|c|c|c|c|c|c|c|c|c|c|c|}
\hline & \multicolumn{3}{|c|}{ employees } & \multicolumn{3}{|c|}{ sales } & \multicolumn{3}{|c|}{ value added } & \multicolumn{3}{|c|}{ profit } & \multicolumn{3}{|c|}{ capital } & \multicolumn{3}{|c|}{ TFP } & \multicolumn{3}{|c|}{ skill intensity } \\
\hline & \multicolumn{3}{|c|}{ OLS estimates } & \multicolumn{3}{|c|}{ OLS estimates } & \multicolumn{3}{|c|}{ OLS estimates } & \multicolumn{3}{|c|}{ OLS estimates } & \multicolumn{3}{|c|}{ OLS estimates } & \multicolumn{3}{|c|}{ OLS estimates } & \multicolumn{3}{|c|}{ Probit estimates } \\
\hline & (1) & (2) & (3) & (1) & (2) & (3) & (1) & (2) & (3) & (1) & (2) & (3) & (1) & (2) & (3) & (1) & (2) & (3) & (1) & (2) & (3) \\
\hline \multirow[t]{2}{*}{ DO_con_excl } & 1.167 & 5.637 & 5.712 & -1264.622 & -1061.08 & -997.987 & 56.398 & 55.386 & 140.804 & 92.113 & 58.680 & 97.401 & 1148879 & 1205622 & 1141191 & 0.083 & 0.065 & 0.067 & -0.156 & -0.124 & -0.122 \\
\hline & $(.747)$ & (.429) & (.407) & (.303) & $(.522)$ & $(.531)$ & $(.860)$ & $(.914)$ & (.764) & $(.579)$ & $(.724)$ & $(.541)$ & (.196) & $(.114)$ & (.114) & $(.562)$ & (.690) & (.686) & (.125) & $(.236)$ & $(.242)$ \\
\hline \multirow[t]{2}{*}{ DI_con_excl } & 17.441 & 17.094 & 15.933 & 1997.467 & 2101.176 & 1804.576 & 1278.09 & 1181.061 & 1246.56 & 297.87 & 252.454 & 334.072 & 73013.06 & 152691.9 & 197013.5 & 0.157 & 0.234 & 0.229 & -0.102 & -0.107 & -0.101 \\
\hline & (.155) & $(.079)^{\star}$ & $(.097)^{\star}$ & $(.469)$ & $(.375)$ & (.436) & $(.213)$ & (.165) & (.131) & (.197) & (.230) & $(.093)^{*}$ & (.874) & $(.789)$ & $(.714)$ & (.283) & (.168) & (.181) & (.355) & $(.340)$ & $(.366)$ \\
\hline \multirow[t]{2}{*}{ FO_con_excl } & 12.382 & 14.829 & 13.491 & 5599.424 & 5901.445 & 5879.318 & 1985.986 & 2045.57 & 2153.008 & 888.703 & 757.910 & 844.273 & 1503604 & 1656954 & 1744445 & 0.245 & 0.284 & 0.274 & -0.104 & -0.150 & -0.144 \\
\hline & $(.074)^{\star}$ & (.173) & $(.203)$ & $(.064)^{\star}$ & $(.124)$ & (.121) & $(.027)^{\star \star}$ & $(.080)^{\star}$ & $(.054)^{\star}$ & $(.069)^{\star}$ & $(.074)^{\star}$ & $(.094)^{\star}$ & (.181) & (.179) & (.141) & (.419) & (.290) & $(.312)$ & (.525) & (.333) & $(.350)$ \\
\hline \multirow[t]{2}{*}{ FI_con_excl } & 331.511 & 290.984 & 295.338 & 359052.5 & 351412.7 & 352589.2 & 173282.3 & 170530.6 & 171155.5 & 37920.92 & 37741.89 & 37915.37 & $4.90 \mathrm{e}+07$ & $4.68 \mathrm{e}+07$ & $4.75 \mathrm{e}+07$ & 1.487 & 1.200 & 0.043 & 0.617 & 0.623 & 0.301 \\
\hline & $(.000)^{\star \star \star}$ & $(.003)^{\star \star \star}$ & $(.003)^{\star \star \star}$ & $(.024)^{\star \star}$ & $(.031)^{\star \star}$ & $(.031)^{\star \star}$ & $(.040)^{\star \star}$ & $(.048)^{\star \star}$ & $(.048)^{\star \star}$ & $(.039)^{\star \star}$ & $(.045)^{\star \star}$ & $(.044)^{\star \star}$ & $(.001)^{\star \star \star}$ & $(.005)^{\star \star \star}$ & $(.004)^{\star \star \star}$ & $(.000)^{\star \star \star}$ & $(.000)^{\star \star \star}$ & $(.009)^{\star \star \star}$ & $(.000)^{\star \star \star}$ & $(.005)^{\star \star \star}$ & $(.007)^{\star \star \star}$ \\
\hline \multirow[t]{2}{*}{ age } & & 0.861 & 0.803 & & 172.760 & 154.740 & & 65.518 & 53.835 & & 8.474 & 4.556 & & 61189.26 & 48692.68 & & -0.003 & -0.003 & & 0.003 & 0.003 \\
\hline & & $(.027)^{\star \star}$ & $(.041)^{\star \star}$ & & $(.047)^{\star \star}$ & $(.077)^{\star}$ & & $(.063)^{\star}$ & (.117) & & $(.206)$ & $(.384)$ & & $(.019)^{\star \star}$ & $(.052)^{\star}$ & & $(.290)$ & $(.307)$ & & (.127) & (.126) \\
\hline \multirow[t]{2}{*}{ export } & & -6.015 & -6.323 & & 323.130 & 254.200 & & -104.370 & -84.822 & & 269.478 & 289.587 & & -250226.8 & -253784.3 & & -0.006 & -0.008 & & 0.113 & 0.112 \\
\hline & & (.544) & $(.526)$ & & $(.887)$ & $(.911)$ & & $(.905)$ & (.923) & & (.135) & (.108) & & (.738) & $(.737)$ & & (.969) & $(.961)$ & & (.243) & $(.243)$ \\
\hline \multirow[t]{2}{*}{ group } & & 34.278 & 28.029 & & 8838.385 & 7241.053 & & 2633.376 & 2008.332 & & -93.607 & -200.991 & & 2247392 & 1465474 & & -0.053 & -0.068 & & 0.134 & 0.139 \\
\hline & & $(.004)^{\star \star \star}$ & $(.013)^{\star \star}$ & & $(.004)^{\star \star \star}$ & $(.011)^{\star \star}$ & & $(.008)^{\star \star \star}$ & $(.018)^{\star \star}$ & & (.810) & $(.580)$ & & $(.021)^{\star \star}$ & $(.057)^{\star}$ & & (.645) & $(.567)$ & & $(.343)$ & (.335) \\
\hline province & & yes & yes & & yes & yes & & yes & yes & & yes & yes & & yes & yes & & yes & yes & & yes & yes \\
\hline industry & & yes & yes & & yes & yes & & yes & yes & & yes & yes & & yes & yes & & yes & yes & & yes & yes \\
\hline obs & 185 & 185 & 179 & 197 & 197 & 191 & 197 & 197 & 191 & 197 & 197 & 191 & 197 & 197 & 191 & 171 & 171 & 162 & 223 & 223 & 214 \\
\hline R2 & .024 & .151 & .139 & .244 & .302 & .312 & .322 & .372 & .390 & .246 & .263 & .311 & .075 & .165 & .188 & .057 & .117 & .119 & .028 & .082 & .091 \\
\hline
\end{tabular}

${ }^{* * *}$ means significant at $1 \%,{ }^{* *}$ at $5 \%,{ }^{*}$ at $10 \%$. Coeffecients and p-values (in parenthesis) are shown. In the skill intensity equation, marginal effects are shown instead of coefficients. 
TABLE 5: Estimation results under the liberal definition of mutually inclusive sourcing strategies, NS included

\begin{tabular}{|c|c|c|c|c|c|c|c|c|c|c|c|c|c|c|c|c|c|c|c|c|c|}
\hline & \multicolumn{3}{|c|}{ employees } & \multicolumn{3}{|c|}{ sales } & \multicolumn{3}{|c|}{ value added } & \multicolumn{3}{|c|}{ profit } & \multicolumn{3}{|c|}{ capital } & \multicolumn{3}{|c|}{ TFP } & \multicolumn{3}{|c|}{ skill intensity } \\
\hline & \multicolumn{3}{|c|}{ OLS estimates } & \multicolumn{3}{|c|}{ OLS estimates } & \multicolumn{3}{|c|}{ OLS estimates } & \multicolumn{3}{|c|}{ OLS estimates } & \multicolumn{3}{|c|}{ OLS estimates } & \multicolumn{3}{|c|}{ OLS estimates } & \multicolumn{3}{|c|}{ Probit estimates } \\
\hline & (1) & (2) & (3) & (1) & (2) & (3) & (1) & (2) & (3) & (1) & (2) & (3) & (1) & (2) & (3) & (1) & (2) & (3) & (1) & (2) & (3) \\
\hline \multirow[t]{2}{*}{ DO_lib_incl } & -3.571 & -5.060 & -2.272 & -17.677 & -2865.905 & -2558.382 & 5143.1 & 3343.44 & 2127.537 & -815.393 & -1377.845 & -738.262 & $\mid-752785.4$ & -523726.6 & 82275.39 & -0.075 & -0.141 & -0.134 & -0.010 & 0.019 & 0.018 \\
\hline & (.903) & $(.794)$ & (.902) & (.998) & (.684) & $(.727)$ & $(.229)$ & $(.310)$ & (.458) & (.451) & (.171) & (.395) & (.699) & (.762) & (.952) & (.571) & $(.322)$ & (.352) & (.910) & (.839) & (.846) \\
\hline \multirow[t]{2}{*}{ DI_lib_incl } & 52.187 & 71.645 & 70.807 & 2274.255 & 6266.998 & 5537.701 & $\mid 1814.952$ & 2151.905 & 2337.891 & 1496.412 & 2690.43 & 2240.232 & 894475.9 & 291865.2 & -76377.58 & -0.034 & 0.143 & 0.183 & -0.140 & -0.152 & -0.146 \\
\hline & $(.005)^{\star \star \star}$ & $(.130)$ & (.136) & (.778) & (.644) & (.680) & (.409) & (.514) & (.464) & (.191) & (.124) & (.188) & $(.799)$ & $(.946)$ & (.985) & (.874) & (.575) & (.482) & (.278) & (.265) & (.285) \\
\hline \multirow[t]{2}{*}{ FO_lib_incl } & 16.568 & 17.431 & -8.979 & 29753.12 & 34133.4 & 29023.5 & 4517.853 & 6485.115 & 10921.75 & 1901.545 & 2628.468 & 3949.786 & 6263249 & 6908731 & 3768459 & -0.033 & -0.003 & 0.005 & -0.039 & -0.117 & -0.108 \\
\hline & (.687) & (.672) & (.796) & (.182) & (.164) & $(.244)$ & (.687) & (.588) & (.391) & $(.420)$ & (.311) & (.149) & $(.262)$ & (.213) & $(.250)$ & (.395) & $(.987)$ & $(.981)$ & $(.796)$ & (.393) & (.429) \\
\hline \multirow[t]{2}{*}{ Fl_lib_incl } & 106.107 & 91.415 & 92.642 & 58396.24 & 52942.34 & 65089.3 & 55951.73 & 51675.8 & 53380.52 & 10024.16 & 9093.516 & 7136.951 & $1.52 \mathrm{e}+07$ & $1.40 \mathrm{e}+07$ & $1.36 \mathrm{e}+07$ & 0.579 & 0.573 & 0.425 & 0.585 & 0.589 & 0.537 \\
\hline & $(.045)^{\star \star}$ & $(.051)^{\star}$ & $(.087)^{\star}$ & $(.065)^{\star}$ & $(.066)^{\star}$ & $(.069)^{\star}$ & $0.075)^{\star}$ & $(.067)^{\star}$ & (.138) & $(.083)^{\star}$ & $(.065)^{*}$ & $(0078)^{\star}$ & $(.063)^{\star}$ & $(.046)^{\star \star}$ & $(.028)^{\star \star}$ & $(.010)^{\star \star \star *}$ & $(.000)^{\star \star \star}$ & $(.001)^{\star \star \star}$ & $(.000)^{\star \star \star}$ & $(.000)^{\star \star \star \star}$ & $(.005)^{\star \star \star}$ \\
\hline \multirow[t]{2}{*}{ age } & & 2.226 & 2.057 & & 185.059 & 133.786 & & 44.552 & -15.614 & & 22.170 & -4.242 & & 147124.1 & 66885.74 & & -0.003 & -0.003 & & 0.002 & 0.002 \\
\hline & & $(.001)^{\star \star \star}$ & $(.003)^{\star \star \star}$ & & (.588) & (.674) & & $(.780)$ & $(.915)$ & & (.595) & (.899) & & $(.028)^{\star \star}$ & (.130) & & (.266) & (.322) & & (.186) & (.180) \\
\hline \multirow[t]{2}{*}{ export } & & 6.316 & 6.127 & & 6685.721 & 6286.838 & & 2771.29 & 3108.169 & & -550.413 & -300.556 & & 757850 & 1485561 & & -0.008 & -0.019 & & 0.147 & 0.144 \\
\hline & & (.715) & (.725) & & (.224) & (.252) & & (.320) & (.275) & & (.525) & $(.714)$ & & (.615) & $(.275)$ & & (.959) & (.905) & & (.126) & (.132) \\
\hline \multirow[t]{2}{*}{ group } & & 31.116 & 23.366 & & 20812.85 & 21034.3 & & 6142.027 & 6891.606 & & 1925.959 & 2174.582 & & 3399614 & 2320362 & & -0.109 & -0.140 & & -0.047 & -0.049 \\
\hline & & $(.206)$ & (.330) & & (.130) & (.162) & & $(.236)$ & $(.225)$ & & (.199) & (.182) & & (.170) & $(.278)$ & & (.342) & (.224) & & (.595) & (.584) \\
\hline province & & yes & yes & & yes & yes & & yes & yes & & yes & yes & & yes & yes & & yes & yes & & yes & yes \\
\hline industry & & yes & yes & & yes & yes & & yes & yes & & yes & yes & & yes & yes & & yes & yes & & yes & yes \\
\hline obs & 190 & 190 & 184 & 202 & 202 & 196 & 199 & 199 & 193 & 202 & 202 & 196 & 202 & 202 & 196 & 173 & 173 & 164 & 225 & 225 & 216 \\
\hline R2 & .028 & .241 & .219 & .096 & .184 & .174 & .195 & .268 & .244 & .127 & .216 & .169 & .104 & .218 & .165 & .036 & .112 & .087 & .032 & .082 & .071 \\
\hline
\end{tabular}

${ }^{* * \star}$ means significant at $1 \%,{ }^{* \star}$ at $5 \%,{ }^{*}$ at $10 \%$. Coeffecients and p-values (in parenthesis) are shown. In the skill intensity equation, marginal effects are shown instead of coefficients. 
TABLE 6: Estimation results under the liberal definition of mutually exclusive sourcing strategies, NS included

\begin{tabular}{|c|c|c|c|c|c|c|c|c|c|c|c|c|c|c|c|c|c|c|c|c|c|}
\hline & \multicolumn{3}{|c|}{ employees } & \multicolumn{3}{|c|}{ sales } & \multicolumn{3}{|c|}{ value added } & \multicolumn{3}{|c|}{ profit } & \multicolumn{3}{|c|}{ capital } & \multicolumn{3}{|c|}{ TFP } & \multicolumn{3}{|c|}{ skill intensity } \\
\hline & \multicolumn{3}{|c|}{ OLS estimates } & \multicolumn{3}{|c|}{ OLS estimates } & \multicolumn{3}{|c|}{ OLS estimates } & \multicolumn{3}{|c|}{ OLS estimates } & \multicolumn{3}{|c|}{ OLS estimates } & \multicolumn{3}{|c|}{ OLS estimates } & \multicolumn{3}{|c|}{ Probit estimates } \\
\hline & (1) & (2) & (3) & (1) & (2) & (3) & (1) & (2) & (3) & (1) & (2) & (3) & (1) & (2) & (3) & (1) & (2) & (3) & (1) & (2) & (3) \\
\hline \multirow[t]{2}{*}{ DO_lib_excl } & 53.086 & 69.878 & 71.975 & 4419.089 & 6416.974 & 6657.641 & 6105.649 & 4814.945 & 4216.381 & 1273.983 & 2067.688 & 2111.109 & 663050.7 & 110085.9 & 317855.2 & -0.087 & -0.013 & -0.033 & -0.114 & -0.096 & -0.095 \\
\hline & (.105) & $(.241)$ & $(.229)$ & $(.624)$ & (.680) & $(.667)$ & $(.037)^{\star \star}$ & $(.320)$ & (.391) & $(.338)$ & $(.282)$ & (.269) & (.862) & $(.981)$ & $(.942)$ & (.698) & $(.960)$ & $(.902)$ & (.359) & (.486) & $(.485)$ \\
\hline \multirow[t]{2}{*}{ DI_lib_excl } & 44.99 & 64.389 & 62.975 & 3687.46 & 9890.717 & 9249.647 & 3288.315 & 3637.994 & 3687.543 & 1419.872 & 2884.331 & 3017.241 & 68445.15 & -605800.2 & -217457.7 & -0.025 & 0.118 & 0.087 & -0.082 & -0.091 & -0.094 \\
\hline & $(.020)^{\star \star}$ & $(.202)$ & $(.206)$ & $(.652)$ & $(.508)$ & $(.526)$ & $(.001)^{\star \star \star}$ & $(.257)$ & $(.228)$ & (.182) & (.119) & $(.094)^{\star}$ & $(.985)$ & (.895) & $(.960)$ & $(.910)$ & $(.664)$ & $(.750)$ & $(.523)$ & (.498) & $(.485)$ \\
\hline \multirow[t]{2}{*}{ FO_lib_excl } & 52.044 & 54.701 & 25.965 & 10080.72 & 14637.09 & 4636.472 & 2728.127 & 3109.336 & 3468.32 & 1287.482 & 2509.833 & 2948.582 & 4543040 & 3516132 & -1729225 & -0.097 & 0.012 & -0.009 & -0.110 & -0.166 & -0.164 \\
\hline & $(.183)$ & $(.329)$ & $(.597)$ & $(.467)$ & (.405) & $(.744)$ & $(.017)^{\star \star}$ & (.425) & $(.352)$ & $(.236)$ & $(.181)$ & $(.107)$ & (.512) & (.619) & (.691) & $(.762)$ & $(.971)$ & $(.978)$ & $(.530)$ & $(.315)$ & $(.315)$ \\
\hline \multirow[t]{2}{*}{ Fl_lib_excl } & 159.98 & 161.763 & 154.254 & 72617.72 & 72569.37 & 81164.87 & 61496.36 & 57945.65 & 61338.14 & 11843.06 & 12191.64 & 10777.31 & $1.80 \mathrm{e}+07$ & $1.65 \mathrm{e}+07$ & $1.47 \mathrm{e}+07$ & 0.524 & 0.605 & 0.448 & 0.557 & 0.553 & 0.444 \\
\hline & $(.002)^{\star \star \star}$ & $(.010)^{\star \star \star}$ & $(.029)^{\star \star}$ & $(.040)^{\star \star}$ & $(.043)^{\star \star}$ & $(.053)^{\star}$ & $(.075)^{\star}$ & $(.070)^{\star}$ & (.130) & $(.057)^{\star}$ & $(.034)^{\star \star}$ & $(.082)^{\star}$ & $(.040)^{\star \star}$ & $(.048)^{\star \star}$ & $(.075)^{\star}$ & $(.091)^{\star}$ & $(.031)^{\star \star}$ & $(.036)^{\star \star}$ & $(.001)^{\star \star \star}$ & $(.008)^{\star \star \star}$ & $(.068)^{*}$ \\
\hline \multirow[t]{2}{*}{ age } & & 2.260 & 2.096 & & 173.845 & 134.440 & & 41.484 & -13.293 & & 22.815 & -5.823 & & 146211.8 & 69703.75 & & -0.003 & -0.003 & & 0.002 & 0.002 \\
\hline & & $(.001)^{\star \star \star}$ & $(.003)^{\star \star \star}$ & & (.630) & (.686) & & (.809) & $(.931)$ & & $(.602)$ & $(.869)$ & & $(.026)^{\star \star}$ & $(.125)$ & & $(.264)$ & $(.298)$ & & $(.204)$ & (.189) \\
\hline \multirow[t]{2}{*}{ export } & & 7.194 & 7.393 & & 8209.935 & 8109.909 & & 2895.616 & 3286.569 & & -480.423 & -142.737 & & 966575.9 & 1856819 & & -0.013 & -0.022 & & 0.146 & 0.143 \\
\hline & & (.681) & $(.675)$ & & (.143) & $(.141)$ & & (.296) & (.228) & & $(.590)$ & $(.860)$ & & (.548) & $(.205)$ & & $(.936)$ & $(.891)$ & & (.131) & (.136) \\
\hline \multirow[t]{2}{*}{ group } & & 28.344 & 20.093 & & 19044.82 & 18200.93 & & 5776.64 & 6255.033 & & 1803.841 & 1908.159 & & 3148473 & 1777198 & & -0.115 & -0.154 & & -0.046 & -0.049 \\
\hline & & $(.254)$ & $(.405)$ & & (.155) & (.198) & & $(.242)$ & $(.244)$ & & $(.210)$ & $(.216)$ & & $(.217)$ & (.396) & & $(.328)$ & $(.205)$ & & (.608) & $(.583)$ \\
\hline province & & yes & yes & & yes & yes & & yes & yes & & yes & yes & & yes & yes & & yes & yes & & yes & yes \\
\hline industry & & yes & yes & & yes & yes & & yes & yes & & yes & yes & & yes & yes & & yes & yes & & yes & yes \\
\hline obs & 190 & 190 & 184 & 202 & 202 & 196 & 199 & 199 & 193 & 202 & 202 & 196 & 202 & 202 & 196 & 173 & 173 & 164 & 225 & 225 & 216 \\
\hline R2 & .027 & .239 & .222 & .076 & .159 & .155 & .187 & .261 & .230 & .121 & .206 & .146 & .094 & .203 & .158 & .034 & .110 & .117 & .028 & .076 & .066 \\
\hline
\end{tabular}

${ }^{* * *}$ means significant at $1 \%,{ }^{* *}$ at $5 \%,{ }^{*}$ at $10 \%$. Coeffecients and p-values (in parenthesis) are shown. In the skill intensity equation, marginal effects are shown instead of coefficients. 


\section{TABLE A1: Variables description}

\begin{tabular}{|c|c|}
\hline variable & description \\
\hline \multirow[t]{3}{*}{ employees } & Firm's number of employees. \\
\hline & Type: regressand. \\
\hline & Source: AIDA. \\
\hline \multirow[t]{3}{*}{ sales } & Firm's sales (thousands of units). \\
\hline & Type: regressand. \\
\hline & Source: AIDA. \\
\hline \multirow[t]{3}{*}{ value added } & Firm's value added (thousands of units). \\
\hline & Type: regressand. \\
\hline & Source: AIDA. \\
\hline \multirow[t]{3}{*}{ profit } & Firm's profit (thousands of units). \\
\hline & Type: regressand. \\
\hline & Source: AIDA. \\
\hline \multirow[t]{3}{*}{ capital } & Firm's tangible fixed assets. \\
\hline & Type: regressand. \\
\hline & Source: AIDA. \\
\hline \multirow[t]{3}{*}{ TFP } & Natural logarithm of firm's total factor productivity (Levinsohn-Petrin estimate). \\
\hline & Type: regressand. \\
\hline & Source: Authors' elaborations from AIDA. \\
\hline \multirow[t]{3}{*}{ skill intensity } & Dummy variable, 1 if the firm's share of graduates is larger than $10 \%, 0$ otherwise. \\
\hline & Type: regressand. \\
\hline & Source: Authors' database. \\
\hline \multirow[t]{3}{*}{ DO_con_incl } & $\begin{array}{l}\text { Dummy variable, } 1 \text { if the firm engages in domestic outsourcing, according to the conservative definition of } \\
\text { mutually inclusive sourcing strategies, } 0 \text { otherwise. }\end{array}$ \\
\hline & Type: core regressor. \\
\hline & Source: Authors' database. \\
\hline \multirow[t]{3}{*}{ DI_con_incl } & $\begin{array}{l}\text { Dummy variable, } 1 \text { if the firm engages in domestic integration, according to the conservative definition of } \\
\text { mutually inclusive sourcing strategies, } 0 \text { otherwise. }\end{array}$ \\
\hline & Type: core regressor. \\
\hline & Source: Authors' database. \\
\hline \multirow[t]{3}{*}{ FO_con_incl } & $\begin{array}{l}\text { Dummy variable, } 1 \text { if the firm engages in foreign outsourcing, according to the conservative definition of } \\
\text { mutually inclusive sourcing strategies, } 0 \text { otherwise. }\end{array}$ \\
\hline & Type: core regressor. \\
\hline & Source: Authors' database. \\
\hline \multirow[t]{3}{*}{ Fl_con_incl } & $\begin{array}{l}\text { Dummy variable, } 1 \text { if the firm engages in foreign integration, according to the conservative definition of } \\
\text { mutually inclusive sourcing strategies, } 0 \text { otherwise. }\end{array}$ \\
\hline & Type: core regressor. \\
\hline & Source: Authors' database. \\
\hline \multirow[t]{3}{*}{ DO_con_excl } & $\begin{array}{l}\text { Dummy variable, } 1 \text { if the firm engages in domestic outsourcing, according to the conservative definition of } \\
\text { mutually exclusive sourcing strategies, } 0 \text { otherwise. }\end{array}$ \\
\hline & Type: core regressor. \\
\hline & Source: Authors' database. \\
\hline \multirow[t]{3}{*}{ DI_con_excl } & $\begin{array}{l}\text { Dummy variable, } 1 \text { if the firm engages in domestic integration, according to the conservative definition of } \\
\text { mutually exclusive sourcing strategies, } 0 \text { otherwise. }\end{array}$ \\
\hline & Type: core regressor. \\
\hline & Source: Authors' database. \\
\hline \multirow[t]{3}{*}{ FO_con_excl } & $\begin{array}{l}\text { Dummy variable, } 1 \text { if the firm engages in foreign outsourcing, according to the conservative definition of } \\
\text { mutually exclusive sourcing strategies, } 0 \text { otherwise. }\end{array}$ \\
\hline & Type: core regressor. \\
\hline & Source: Authors' database. \\
\hline
\end{tabular}




\begin{tabular}{|c|c|}
\hline FI_con_excl & $\begin{array}{l}\text { Dummy variable, } 1 \text { if the firm engages in foreign integration, according to the conservative definition of } \\
\text { mutually exclusive sourcing strategies, } 0 \text { otherwise. } \\
\text { Type: core regressor. } \\
\text { Source: Authors' database. }\end{array}$ \\
\hline DO_lib_incl & $\begin{array}{l}\text { Dummy variable, } 1 \text { if the firm engages in domestic outsourcing, according to the liberal definition of } \\
\text { mutually inclusive sourcing strategies, } 0 \text { otherwise. } \\
\text { Type: core regressor. } \\
\text { Source: Authors' database. }\end{array}$ \\
\hline DI_lib_incl & $\begin{array}{l}\text { Dummy variable, } 1 \text { if the firm engages in domestic integration, according to the liberal definition of mutually } \\
\text { inclusive sourcing strategies, } 0 \text { otherwise. } \\
\text { Type: core regressor. } \\
\text { Source: Authors' database. }\end{array}$ \\
\hline FO_lib_incl & $\begin{array}{l}\text { Dummy variable, } 1 \text { if the firm engages in foreign outsourcing, according to the liberal definition of mutually } \\
\text { inclusive sourcing strategies, } 0 \text { otherwise. } \\
\text { Type: core regressor. } \\
\text { Source: Authors' database. }\end{array}$ \\
\hline FI_lib_incl & $\begin{array}{l}\text { Dummy variable, } 1 \text { if the firm engages in foreign integration, according to the liberal definition of mutually } \\
\text { inclusive sourcing strategies, } 0 \text { otherwise. } \\
\text { Type: core regressor. } \\
\text { Source: Authors' database. }\end{array}$ \\
\hline DO_lib_excl & $\begin{array}{l}\text { Dummy variable, } 1 \text { if the firm engages in domestic outsourcing, according to the liberal definition of } \\
\text { mutually exclusive sourcing strategies, } 0 \text { otherwise. } \\
\text { Type: core regressor. } \\
\text { Source: Authors' database. }\end{array}$ \\
\hline DI_lib_excl & $\begin{array}{l}\text { Dummy variable, } 1 \text { if the firm engages in domestic integration, according to the liberal definition of mutually } \\
\text { exclusive sourcing strategies, } 0 \text { otherwise. } \\
\text { Type: core regressor. } \\
\text { Source: Authors' database. }\end{array}$ \\
\hline FO_lib_excl & $\begin{array}{l}\text { Dummy variable, } 1 \text { if the firm engages in foreign outsourcing, according to the liberal definition of mutually } \\
\text { exclusive sourcing strategies, } 0 \text { otherwise. } \\
\text { Type: core regressor. } \\
\text { Source: Authors' database. }\end{array}$ \\
\hline Fl_lib_excl & $\begin{array}{l}\text { Dummy variable, } 1 \text { if the firm engages in foreign integration, according to the liberal definition of mutually } \\
\text { exclusive sourcing strategies, } 0 \text { otherwise. } \\
\text { Type: core regressor. } \\
\text { Source: Authors' database. }\end{array}$ \\
\hline age & $\begin{array}{l}\text { Firm's age, defined as the difference between } 2009 \text { and the year of firm's establishment. } \\
\text { Type: control regressor. } \\
\text { Source: Authors' database. }\end{array}$ \\
\hline export & $\begin{array}{l}\text { Dummy variable, } 1 \text { if the firm engages in export operations, } 0 \text { otherwise. } \\
\text { Type: control regressor. } \\
\text { Source: Authors' database. }\end{array}$ \\
\hline group & $\begin{array}{l}\text { Dummy variable, } 1 \text { if the firm belongs to a group, } 0 \text { otherwise. } \\
\text { Type: control regressor. } \\
\text { Source: Authors' database. }\end{array}$ \\
\hline
\end{tabular}


TABLE A2: Summary statistics of firm-level regressors

\begin{tabular}{|lrrrrr|}
\hline variable & obs & mean & std.dev. & min & max \\
\hline DO_con_incl & 228 & 0.422 & 0.495 & 0 & 1 \\
DI_con_incl & 228 & 0.704 & 0.458 & 0 & 1 \\
FO_con_incl & 228 & 0.080 & 0.272 & 0 & 1 \\
FI_con_incl & 228 & 0.027 & 0.161 & 0 & 1 \\
DO_con_excl & 228 & 0.354 & 0.479 & 0 & 1 \\
DI_con_excl & 228 & 0.296 & 0.458 & 0 & 1 \\
FO_con_excl & 228 & 0.076 & 0.266 & 0 & 1 \\
FI_con_excl & 228 & 0.027 & 0.162 & 0 & 1 \\
DO_lib_incl & 228 & 0.575 & 0.495 & 0 & 1 \\
DI_lib_incl & 228 & 0.934 & 0.248 & 0 & 1 \\
FO_lib_incl & 228 & 0.118 & 0.324 & 0 & 1 \\
FI_lib_incl & 228 & 0.075 & 0.263 & 0 & 1 \\
DO_lib_excl & 228 & 0.434 & 0.497 & 0 & 1 \\
DI_lib_excl & 228 & 0.342 & 0.475 & 0 & 1 \\
FO_lib_excl & 228 & 0.092 & 0.290 & 0 & 1 \\
Fl_lib_excl & 228 & 0.075 & 0.263 & 0 & 1 \\
age & 228 & 39.833 & 26.069 & 0 & 1 \\
export & 228 & 0.803 & 0.803 & 0 & 1 \\
group & 228 & 0.232 & 0.423 & 0 & 1 \\
\hline
\end{tabular}


TABLE A3: Correlations between firm-level regressors

\begin{tabular}{|c|c|c|c|c|c|c|c|c|c|c|c|c|c|c|c|c|c|c|c|}
\hline & 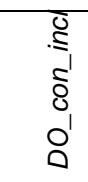 & 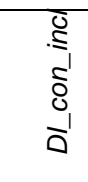 & 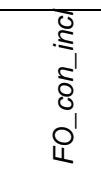 & 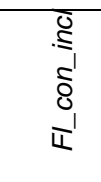 & 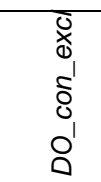 & 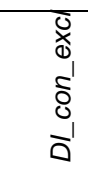 & 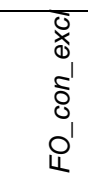 & $\begin{array}{l}\bar{u} \\
\bar{x} \\
\vdots \\
\delta \\
d \\
\bar{u} \\
1\end{array}$ & $\begin{array}{l}\bar{\Xi} \\
\stackrel{\Xi}{=} \\
\cong \\
o \\
o \\
0\end{array}$ & 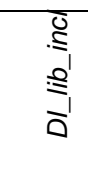 & 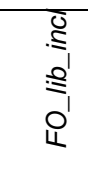 & 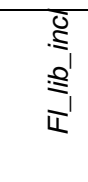 & $\begin{array}{l}\bar{v} \\
\text { d } \\
\stackrel{0}{\prime} \\
0 \\
0 \\
0\end{array}$ & 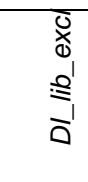 & $\begin{array}{l}\overline{\bar{x}} \\
\bar{d} \\
\vdots \\
\vdots \\
0 \\
0\end{array}$ & 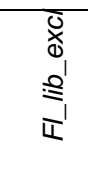 & $\underset{\widetilde{D}}{\mathbb{\Phi}}$ & $\begin{array}{l}\frac{1}{2} \\
\frac{1}{8} \\
0\end{array}$ & $\begin{array}{l}\frac{2}{3} \\
\frac{5}{3}\end{array}$ \\
\hline DO_con_incl & 1.00 & & & & & & & & & & & & & & & & & & \\
\hline DI_con_incl & .361 & 1.00 & & & & & & & & & & & & & & & & & \\
\hline FO_con_incl & .146 & .051 & 1.00 & & & & & & & & & & & & & & & & \\
\hline Fl_con_incl & .083 & .047 & .053 & 1.00 & & & & & & & & & & & & & & & \\
\hline DO_con_excl & .868 & .342 & -.220 & -.123 & 1.00 & & & & & & & & & & & & & & \\
\hline DI_con_excl & -.554 & .425 & -.192 & -.108 & -.480 & 1.00 & & & & & & & & & & & & & \\
\hline FO_con_excl & .131 & .041 & .970 & -.048 & -.213 & -.186 & 1.00 & & & & & & & & & & & & \\
\hline Fl_con_excl & .083 & .049 & .053 & 1.00 & -.123 & -.108 & -.048 & 1.00 & & & & & & & & & & & \\
\hline DO_lib_incl & .744 & .338 & .191 & .088 & .650 & -.422 & .184 & .090 & 1.00 & & & & & & & & & & \\
\hline DI_lib_incl & .229 & .411 & .079 & -.067 & .199 & .174 & .077 & -.066 & .273 & 1.00 & & & & & & & & & \\
\hline FO_lib_incl & .171 & .120 & .853 & .109 & -.136 & -.194 & .827 & .121 & .261 & .097 & 1.00 & & & & & & & & \\
\hline FI_lib_incl & .009 & .017 & .110 & .619 & -.114 & -.127 & .065 & .643 & .109 & .008 & .206 & 1.00 & & & & & & & \\
\hline DO_lib_excl & .584 & .241 & -.261 & -.146 & .735 & -.283 & -.257 & -.149 & .754 & .197 & -.321 & -.249 & 1.00 & & & & & & \\
\hline DI_lib_excl & -.623 & -.120 & -.215 & -.120 & -.543 & .534 & -.211 & -.122 & -.838 & .191 & -.264 & -.205 & -.632 & 1.00 & & & & & \\
\hline FO_lib_excl & .194 & .074 & .794 & -.053 & -.125 & -.163 & .820 & -.051 & .213 & .085 & .869 & -.090 & -.279 & -.230 & 1.00 & & & & \\
\hline FI_lib_excl & .009 & .017 & .110 & .619 & -.114 & -.127 & .065 & .643 & .109 & .008 & .206 & 1.00 & -.249 & -.205 & -.090 & 1.00 & & & \\
\hline age & -.070 & .131 & .016 & -.029 & -.136 & .176 & .041 & -.029 & -.093 & .076 & .050 & .008 & -.149 & .122 & .111 & .008 & 1.00 & & \\
\hline export & .072 & .040 & .102 & .082 & .006 & -.057 & .098 & .081 & .041 & .135 & .079 & .057 & -.010 & .009 & .082 & .057 & .238 & 1.00 & \\
\hline group & .034 & .039 & -.048 & .233 & .027 & -.062 & -.081 & .233 & .012 & -.063 & -.009 & .200 & .000 & -.069 & -.104 & .200 & .018 & .090 & 1.00 \\
\hline
\end{tabular}


TABLE B1: Estimation results under the conservative definition of mutually inclusive sourcing strategies, NS excluded

\begin{tabular}{|c|c|c|c|c|c|c|c|c|c|c|c|c|c|c|c|c|c|c|c|c|c|}
\hline & \multicolumn{3}{|c|}{ employees } & \multicolumn{3}{|c|}{ sales } & \multicolumn{3}{|c|}{ value added } & \multicolumn{3}{|c|}{ profit } & \multicolumn{3}{|c|}{ capital } & \multicolumn{3}{|c|}{ TFP } & \multicolumn{3}{|c|}{ skill intensity } \\
\hline & \multicolumn{3}{|c|}{ OLS estimates } & \multicolumn{3}{|c|}{ OLS estimates } & \multicolumn{3}{|c|}{ OLS estimates } & \multicolumn{3}{|c|}{ OLS estimates } & \multicolumn{3}{|c|}{ OLS estimates } & \multicolumn{3}{|c|}{ OLS estimates } & \multicolumn{3}{|c|}{ Probit estimates } \\
\hline & (1) & (2) & (3) & (1) & (2) & (3) & (1) & (2) & (3) & (1) & (2) & (3) & (1) & (2) & (3) & (1) & (2) & (3) & (1) & (2) & (3) \\
\hline DO_con_incl & $\begin{array}{c}-16.012 \\
(.170)\end{array}$ & $\begin{array}{c}-13.305 \\
(.151)\end{array}$ & $\begin{array}{c}-10.382 \\
(.229)\end{array}$ & $\begin{array}{c}-3008.677 \\
(.228)\end{array}$ & $\begin{array}{c}-3379.941 \\
(.118)\end{array}$ & $\begin{array}{c}-2550.671 \\
(.213)\end{array}$ & $\begin{array}{c}-994.473 \\
(.307)\end{array}$ & $\begin{array}{c}-1076.53 \\
(.193)\end{array}$ & $\begin{array}{c}-908.833 \\
(.254)\end{array}$ & $\begin{array}{c}-143.212 \\
(.424)\end{array}$ & $\begin{array}{c}-159.733 \\
(.398)\end{array}$ & $\begin{array}{c}-157.779 \\
(.386)\end{array}$ & $\begin{array}{c}-1172671 \\
(.182)\end{array}$ & $\begin{array}{c}-1142071 \\
(.112)\end{array}$ & $\begin{array}{c}-957369.8 \\
(.154)\end{array}$ & $\begin{array}{l}-0.052 \\
(.761)\end{array}$ & $\begin{array}{l}-0.180 \\
(.422)\end{array}$ & $\begin{array}{l}-0.170 \\
(.410)\end{array}$ & $\begin{array}{l}-0.019 \\
(.851)\end{array}$ & $\begin{array}{l}0.001 \\
(.993)\end{array}$ & $\begin{array}{l}-0.045 \\
(.671)\end{array}$ \\
\hline DI_con_incl & $\begin{array}{l}-1.260 \\
(.846)\end{array}$ & $\begin{array}{l}-27.185 \\
(.096)^{\star}\end{array}$ & $\begin{array}{l}-24.158 \\
(.088)^{\star}\end{array}$ & $\begin{array}{c}-4321.578 \\
(.163)\end{array}$ & $\begin{array}{c}-9465.637 \\
(.021)^{\star \star}\end{array}$ & $\begin{array}{l}-7715.9 \\
(.026)^{\star \star}\end{array}$ & $\begin{array}{c}-812.712 \\
(.385)\end{array}$ & $\begin{array}{c}-2399.291 \\
(.097)^{*}\end{array}$ & $\begin{array}{c}-2000.79 \\
(.105)\end{array}$ & $\begin{array}{c}-717.243 \\
(.133)\end{array}$ & $\begin{array}{c}-816.959 \\
(.096)^{\star}\end{array}$ & $\begin{array}{c}-684.464 \\
(.082)^{\star}\end{array}$ & $\begin{array}{c}70962.85 \\
(.953)\end{array}$ & $\begin{array}{c}-1535505 \\
(.261)\end{array}$ & $\begin{array}{c}-1246793 \\
(.261)\end{array}$ & $\begin{array}{l}0.047 \\
(.831)\end{array}$ & $\begin{array}{l}0.032 \\
(.878)\end{array}$ & $\begin{array}{l}0.032 \\
(.858)\end{array}$ & $\begin{array}{l}0.008 \\
(.957)\end{array}$ & $\begin{array}{l}-0.052 \\
(.755)\end{array}$ & $\begin{array}{l}-0.142 \\
(.377)\end{array}$ \\
\hline FO_con_incl & $\begin{array}{l}6.562 \\
(.431)\end{array}$ & $\begin{array}{l}-3.972 \\
(.823)\end{array}$ & $\begin{array}{l}-4.288 \\
(.801)\end{array}$ & $\begin{array}{c}5842.937 \\
(.027)^{\star \star}\end{array}$ & $\begin{array}{c}5195.015 \\
(.162)\end{array}$ & $\begin{array}{c}5775.902 \\
(.121)\end{array}$ & $\begin{array}{c}1976.053 \\
(.052)^{*}\end{array}$ & $\begin{array}{c}1821.473 \\
(.201)\end{array}$ & $\begin{array}{c}1970.366 \\
(.166)\end{array}$ & $\begin{array}{c}639.822 \\
(.078)^{\star}\end{array}$ & $\begin{array}{c}604.260 \\
(.161)\end{array}$ & $\begin{array}{c}691.170 \\
(.125)\end{array}$ & $\begin{array}{c}1321704 \\
(.166)\end{array}$ & $\begin{array}{c}914863.5 \\
(.429)\end{array}$ & $\begin{array}{c}1044967 \\
(.345)\end{array}$ & $\begin{array}{l}0.160 \\
(.613)\end{array}$ & $\begin{array}{l}0.231 \\
(.367)\end{array}$ & $\begin{array}{l}0.219 \\
(.398)\end{array}$ & $\begin{array}{l}0.034 \\
(.836)\end{array}$ & $\begin{array}{l}-0.054 \\
(.731)\end{array}$ & $\begin{array}{l}-0.074 \\
(.635)\end{array}$ \\
\hline FI_con_incl & $\begin{array}{l}323.418 \\
(.000)^{\star \star \star *}\end{array}$ & $\begin{array}{l}262.422 \\
(.008)^{\star \star \star}\end{array}$ & $\begin{array}{l}266.451 \\
(.009)^{* \star *}\end{array}$ & $\begin{array}{c}356795.3 \\
(.024)^{\star \star}\end{array}$ & $\begin{array}{c}344231.8 \\
(.034)^{\star \star}\end{array}$ & $\begin{array}{c}345224.7 \\
(.034)^{\star \star}\end{array}$ & $\begin{array}{c}171981.1 \\
(.042)^{\star *}\end{array}$ & $\begin{array}{c}168131.8 \\
(.052)^{*}\end{array}$ & $\begin{array}{c}168301.4 \\
(.052)^{\star}\end{array}$ & $\begin{array}{l}37477.75 \\
(.040)^{\star \star}\end{array}$ & $\begin{array}{c}37166.42 \\
(.046)^{\star \star}\end{array}$ & $\begin{array}{c}37045.86 \\
(.047)^{* *}\end{array}$ & $\begin{array}{l}4.80 \mathrm{e}+07 \\
(.001)^{\star \star \star}\end{array}$ & $\begin{array}{l}4.56 \mathrm{e}+07 \\
(.007)^{\star \star \star}\end{array}$ & $\begin{array}{l}4.61 \mathrm{e}+07 \\
(.007)^{\star \star \star}\end{array}$ & $\begin{array}{c}1.385 \\
(.000)^{\star \star *}\end{array}$ & $\begin{array}{l}1.038 \\
(.077)^{\star}\end{array}$ & $\begin{array}{c}0.021 \\
(.096)^{\star}\end{array}$ & $\begin{array}{c}0.669 \\
(.000)^{\star \star *}\end{array}$ & $\begin{array}{c}0.703 \\
(.002)^{\star \star \star}\end{array}$ & $\begin{array}{c}0.443 \\
(.007)^{* \star *}\end{array}$ \\
\hline age & & $\begin{array}{l}1.209 \\
(.039)^{\star \star}\end{array}$ & $\begin{array}{c}1.176 \\
(.045)^{\star \star}\end{array}$ & & $\begin{array}{l}255.435 \\
(.044)^{\star \star}\end{array}$ & $\begin{array}{l}239.870 \\
(.058)^{\star}\end{array}$ & & $\begin{array}{l}84.430 \\
(.098)^{\star}\end{array}$ & $\begin{array}{l}81.131 \\
(.113)\end{array}$ & & $\begin{array}{l}6.393 \\
(.330)\end{array}$ & $\begin{array}{l}6.587 \\
(.321)\end{array}$ & & $\begin{array}{c}84811.11 \\
(.019)^{\star \star}\end{array}$ & $\begin{array}{c}75749.27 \\
(.032)^{\star *}\end{array}$ & & $\begin{array}{l}-0.005 \\
(.256)\end{array}$ & $\begin{array}{l}-0.004 \\
(.268)\end{array}$ & & $\begin{array}{l}0.004 \\
(.085)^{\star}\end{array}$ & $\begin{array}{l}0.004 \\
(.094)^{\star}\end{array}$ \\
\hline export & & $\begin{array}{c}-13.870 \\
(.356)\end{array}$ & $\begin{array}{c}-15.175 \\
(.317)\end{array}$ & & $\begin{array}{c}-1878.459 \\
(.558)\end{array}$ & $\begin{array}{c}-2200.577 \\
(.496)\end{array}$ & & $\begin{array}{c}-809.489 \\
(.529)\end{array}$ & $\begin{array}{c}-876.346 \\
(.500)\end{array}$ & & $\begin{array}{c}103.814 \\
(.567)\end{array}$ & $\begin{array}{l}96.774 \\
(.586)\end{array}$ & & $\begin{array}{c}-811100.8 \\
(.434)\end{array}$ & $\begin{array}{c}-862935 \\
(.412)\end{array}$ & & $\begin{array}{l}-0.082 \\
(.694)\end{array}$ & $\begin{array}{r}-0.086 \\
(.671)\end{array}$ & & $\begin{array}{l}0.115 \\
(.311)\end{array}$ & $\begin{array}{l}0.130 \\
(.244)\end{array}$ \\
\hline group & & $\begin{array}{l}58.955 \\
(.016)^{\star *}\end{array}$ & $\begin{array}{l}50.293 \\
(.033)^{\star \star}\end{array}$ & & $\begin{array}{l}17271.41 \\
(.002)^{\star \star \star}\end{array}$ & $\begin{array}{l}15172.11 \\
(.005)^{\star \star \star}\end{array}$ & & $\begin{array}{l}4776.992 \\
(.008)^{\star \star \star \star}\end{array}$ & $\begin{array}{c}4373.353 \\
(.014)^{\star \star}\end{array}$ & & $\begin{array}{c}412.425 \\
(.281)\end{array}$ & $\begin{array}{c}519.913 \\
(.193)\end{array}$ & & $\begin{array}{c}2842884 \\
(.053)^{\star}\end{array}$ & $\begin{array}{c}1909744 \\
(.091)^{\star}\end{array}$ & & $\begin{array}{l}-0.156 \\
(.417)\end{array}$ & $\begin{array}{l}-0.191 \\
(.344)\end{array}$ & & $\begin{array}{l}0.152 \\
(.383)\end{array}$ & $\begin{array}{l}0.178 \\
(.331)\end{array}$ \\
\hline $\begin{array}{l}\text { province } \\
\text { industry }\end{array}$ & & $\begin{array}{l}\text { yes } \\
\text { yes }\end{array}$ & $\begin{array}{l}\text { yes } \\
\text { yes }\end{array}$ & & $\begin{array}{l}\text { yes } \\
\text { yes }\end{array}$ & $\begin{array}{l}\text { yes } \\
\text { yes }\end{array}$ & & $\begin{array}{l}\text { yes } \\
\text { yes }\end{array}$ & $\begin{array}{l}\text { yes } \\
\text { yes }\end{array}$ & & $\begin{array}{l}\text { yes } \\
\text { yes }\end{array}$ & $\begin{array}{l}\text { yes } \\
\text { yes }\end{array}$ & & $\begin{array}{l}\text { yes } \\
\text { yes }\end{array}$ & $\begin{array}{l}\text { yes } \\
\text { yes }\end{array}$ & & $\begin{array}{l}\text { yes } \\
\text { yes }\end{array}$ & $\begin{array}{l}\text { yes } \\
\text { yes }\end{array}$ & & $\begin{array}{l}\text { yes } \\
\text { yes }\end{array}$ & $\begin{array}{l}\text { yes } \\
\text { yes }\end{array}$ \\
\hline obs & 142 & 142 & 139 & 150 & 150 & 147 & 150 & 150 & 147 & 150 & 150 & 147 & 150 & 150 & 147 & 131 & 131 & 126 & 168 & 168 & 163 \\
\hline R2 & .022 & .191 & .183 & .265 & .361 & .368 & .350 & .412 & .414 & .331 & .344 & .346 & .088 & .210 & .245 & .055 & .163 & .171 & 0.022 & .097 & .098 \\
\hline
\end{tabular}

${ }^{* * *}$ means significant at $1 \%,{ }^{* *}$ at $5 \%,{ }^{*}$ at $10 \%$. Coeffecients and p-values (in parenthesis) are shown. In the skill intensity equation, marginal effects are shown instead of coefficients. 
TABLE B2: Estimation results under the conservative definition of mutually exclusive sourcing strategies, NS excluded

\begin{tabular}{|c|c|c|c|c|c|c|c|c|c|c|c|c|c|c|c|c|c|c|c|c|c|}
\hline & \multicolumn{3}{|c|}{ employees } & \multicolumn{3}{|c|}{ sales } & \multicolumn{3}{|c|}{ value added } & \multicolumn{3}{|c|}{ profit } & \multicolumn{3}{|c|}{ capital } & \multicolumn{3}{|c|}{ TFP } & \multicolumn{3}{|c|}{ skill intensity } \\
\hline & \multicolumn{3}{|c|}{ OLS estimates } & \multicolumn{3}{|c|}{ OLS estimates } & \multicolumn{3}{|c|}{ OLS estimates } & \multicolumn{3}{|c|}{ OLS estimates } & \multicolumn{3}{|c|}{ OLS estimates } & \multicolumn{3}{|c|}{ OLS estimates } & \multicolumn{3}{|c|}{ Probit estimates } \\
\hline & (1) & (2) & (3) & (1) & (2) & (3) & (1) & (2) & (3) & (1) & (2) & (3) & (1) & (2) & (3) & (1) & (2) & (3) & (1) & (2) & (3) \\
\hline \multirow[t]{2}{*}{ DO_con_excl } & -16.273 & -9.276 & -8.614 & -3262.089 & -3083.926 & -2789.127 & -1221.692 & -1107.385 & -1063.517 & -205.756 & -239.654 & -265.280 & -1075866 & -806719.8 & -724778.9 & -0.073 & -0.208 & -0.195 & -0.052 & -0.024 & -0.067 \\
\hline & (.189) & $(.337)$ & $(.356)$ & $(.217)$ & (.187) & $(.214)$ & $(.234)$ & $(.213)$ & $(.219)$ & $(.256)$ & $(.258)$ & (.180) & $(.244)$ & $(.277)$ & $(.320)$ & (.657) & $(.323)$ & (.328) & (.612) & $(.822)$ & $(.539)$ \\
\hline \multirow[t]{2}{*}{ FO_con_excl } & -5.059 & 0.330 & -0.688 & 3601.958 & 5022.435 & 5211.266 & 707.895 & 1197.396 & 1234.066 & 590.833 & 601.889 & 619.731 & 354724.8 & 672573.8 & 760711.2 & 0.087 & 0.055 & 0.052 & -0.004 & -0.048 & -0.075 \\
\hline & $(.711)$ & $(.981)$ & $(.961)$ & $(.345)$ & $(.222)$ & $(.200)$ & $(.591)$ & (.353) & (.338) & $(.231)$ & $(.232)$ & $(.222)$ & $(.797)$ & (.608) & $(.544)$ & $(.781)$ & $(.831)$ & (.838) & (.978) & $(.766)$ & (.639) \\
\hline \multirow[t]{2}{*}{ FI_con_excl } & 314.070 & 261.418 & 265.676 & 357055 & 344634.6 & 346225 & 172004.2 & 168223.8 & 168522.6 & 37623.05 & 37298.84 & 37207.71 & $4.79 \mathrm{e}+07$ & $4.54 \mathrm{e}+07$ & $4.61 \mathrm{e}+07$ & 1.329 & 0.983 & -0.162 & 0.666 & 0.705 & 0.353 \\
\hline & $(.000)^{\star \star \star}$ & $(.011)^{\star \star}$ & $(.011)^{\star \star}$ & $(.025)^{\star \star}$ & $(.034)^{\star \star}$ & $(.034)^{\star \star}$ & $(.042)^{\star \star}$ & $(.052)^{*}$ & $(.052)^{\star}$ & $(.041)^{\star \star}$ & $(.046)^{\star \star}$ & $(.046)^{\star \star}$ & $(.002)^{\star \star \star}$ & $(.008)^{\star \star \star}$ & $(.007)^{\star \star \star}$ & $(.000)^{\star \star \star}$ & $(.042)^{* *}$ & $(.058)^{*}$ & $(.000)^{\star \star \star}$ & $(.000)^{\star \star \star}$ & $(.003)^{\star \star \star}$ \\
\hline \multirow[t]{2}{*}{ age } & & 1.138 & 1.092 & & 223.870 & 208.913 & & 76.106 & 72.878 & & 3.142 & 3.420 & & 80960.08 & 71834.69 & & -0.005 & -0.005 & & 0.004 & 0.003 \\
\hline & & $(.040)^{\star \star}$ & $(.048)^{\star \star}$ & & $(.066)^{\star}$ & $(.083)^{\star}$ & & (.114) & (.130) & & (.637) & (.605) & & $(.019)^{\star \star}$ & $(.032)^{\star \star}$ & & $(.247)$ & (.253) & & (.108) & (.153) \\
\hline \multirow[t]{2}{*}{ export } & & -14.101 & -14.218 & & -1667.972 & -1742.865 & & -710.607 & -718.797 & & 153.421 & 160.053 & & -873073.1 & -874266.5 & & -0.087 & -0.092 & & 0.120 & 0.138 \\
\hline & & $(.346)$ & $(.337)$ & & $(.606)$ & $(.587)$ & & $(.582)$ & $(.575)$ & & $(.399)$ & (.363) & & (.402) & (.404) & & $(.664)$ & (.639) & & $(.285)$ & $(.214)$ \\
\hline \multirow[t]{2}{*}{ group } & & 56.080 & 47.593 & & 16249.28 & 14251.82 & & 4499.399 & 4113.343 & & 344.259 & 457.663 & & 2620310 & 1693704 & & -0.146 & -0.181 & & 0.149 & 0.156 \\
\hline & & $(.017)^{\star \star}$ & $(.035)^{\star \star}$ & & $(.003)^{\star \star \star}$ & $(.006)^{\star \star \star}$ & & $(.009)^{\star \star \star}$ & $(.016)^{\star \star}$ & & (.353) & $(.237)$ & & $(.066)^{\star}$ & (.120) & & (.423) & (.339) & & $(.387)$ & (.382) \\
\hline province & & yes & yes & & yes & yes & & yes & yes & & yes & yes & & yes & yes & & yes & yes & & yes & yes \\
\hline industry & & yes & yes & & yes & yes & & yes & yes & & yes & yes & & yes & yes & & yes & yes & & yes & yes \\
\hline obs & 142 & 142 & 139 & 150 & 150 & 147 & 150 & 150 & 147 & 150 & 150 & 147 & 150 & 150 & 147 & 131 & 131 & 126 & 168 & 168 & 163 \\
\hline R2 & .021 & 181 & 174 & .262 & 347 & .356 & 349 & .405 & .408 & .321 & .332 & 336 & .084 & .202 & .236 & .056 & .165 & .173 & .024 & .096 & .098 \\
\hline
\end{tabular}

*** means significant at $1 \%,{ }^{* *}$ at $5 \%,{ }^{*}$ at $10 \%$. Coeffecients and p-values (in parenthesis) are shown. In the skill intensity equation, marginal effects are shown instead of coefficients. 
TABLE B3: Estimation results under the liberal definition of mutually inclusive sourcing strategies, NS excluded

\begin{tabular}{|c|c|c|c|c|c|c|c|c|c|c|c|c|c|c|c|c|c|c|c|c|c|}
\hline & \multicolumn{3}{|c|}{ employees } & \multicolumn{3}{|c|}{ sales } & \multicolumn{3}{|c|}{ value added } & \multicolumn{3}{|c|}{ profit } & \multicolumn{3}{|c|}{ capital } & \multicolumn{3}{|c|}{ TFP } & \multicolumn{3}{|c|}{ skill intensity } \\
\hline & \multicolumn{3}{|c|}{ OLS estimates } & \multicolumn{3}{|c|}{ OLS estimates } & \multicolumn{3}{|c|}{ OLS estimates } & \multicolumn{3}{|c|}{ OLS estimates } & \multicolumn{3}{|c|}{ OLS estimates } & \multicolumn{3}{|c|}{ OLS estimates } & \multicolumn{3}{|c|}{ Probit estimates } \\
\hline & (1) & (2) & (3) & (1) & (2) & (3) & (1) & (2) & (3) & (1) & (2) & (3) & (1) & (2) & (3) & (1) & (2) & (3) & (1) & (2) & (3) \\
\hline \multirow[t]{2}{*}{ DO_lib_incl } & -3.175 & -7.587 & -4.982 & 213.423 & -3905.575 & -3772.974 & 5268.526 & 3101.2 & 1890.227 & $\mid-850.320$ & -1586.921 & -955.716 & -685206.5 & -574194.9 & -61616.65 & -0.078 & -0.163 & -0.133 & -0.026 & 0.027 & 0.026 \\
\hline & $(.915)$ & $(.667)$ & $(.765)$ & $(.977)$ & $(.598)$ & $(.620)$ & $(.234)$ & $(.341)$ & (.497) & $(.440)$ & (.125) & (.294) & $(.730)$ & (.749) & $(.965)$ & $(.556)$ & $(.258)$ & $(.380)$ & $(.770)$ & $(.757)$ & $(.764)$ \\
\hline \multirow[t]{2}{*}{ DI_lib_incl } & 71.264 & 109.337 & 113.734 & 14047.85 & -4638.151 & -6574.229 & 10358.38 & 9497.06 & 12205.02 & -282.939 & -2392.003 & -2880.505 & 4337333 & 5240617 & 4519420 & -0.117 & 0.320 & 0.841 & -0.117 & 0.320 & 0.841 \\
\hline & $(.013)^{\star \star}$ & $(.000)^{\star \star \star}$ & $(.000)^{\star \star \star}$ & $(.023)^{\star \star}$ & (.858) & (.808) & $(.394)$ & $(.504)$ & (.389) & $(.742)$ & $(.384)$ & (.321) & $(.002)^{\star \star \star}$ & $(.123)$ & (.197) & $(.850)$ & (.401) & $(.000)^{\star \star \star \star}$ & $(.851)$ & $(.402)$ & (.504) \\
\hline \multirow[t]{2}{*}{ FO_lib_incl } & 16.439 & 16.434 & -11.109 & 29674.29 & 34586.19 & 29411.85 & 4992.504 & 7058.056 & 11595.86 & $\mid 1913.458$ & 2713.211 & 4042.512 & 6240197 & 6970573 & 3742675 & -0.030 & -0.005 & -0.008 & -0.108 & -0.178 & -0.175 \\
\hline & $(.690)$ & $(.704)$ & $(.765)$ & (.184) & (.164) & $(.246)$ & $(.677)$ & $(.586)$ & (.399) & $(.418)$ & $(.301)$ & (.145) & (.264) & $(.211)$ & (.262) & $(.904)$ & $(.982)$ & $(.971)$ & (.491) & (.188) & (.198) \\
\hline \multirow[t]{2}{*}{ FI_lib_incl } & 106.101 & 94.658 & 97.002 & 58390.19 & 52649.42 & 65333.44 & \begin{tabular}{|l|}
55796.3 \\
\end{tabular} & 51105.65 & 53104.59 & 10025.07 & 9104.613 & 7253.24 & $1.52 \mathrm{e}+07$ & $1.38 \mathrm{e}+07$ & $1.35 \mathrm{e}+07$ & 0.558 & 0.538 & 0.414 & 0.573 & 0.523 & 0.533 \\
\hline & $(.045)^{\star \star}$ & $(.042)^{\star \star}$ & $(.074)^{\star}$ & $(.066)^{\star}$ & $(.058)^{\star}$ & $(.054)^{\star}$ & $(.074)^{\star}$ & $(.063)^{\star}$ & (.132) & $(.083)^{\star}$ & $(.060)^{\star}$ & (.138) & $(.063)^{\star}$ & $(.048)^{\star \star}$ & $(.029)^{\star \star}$ & $(.008)^{\star \star \star *}$ & $(.000)^{\star \star \star \star}$ & $(.004)^{\star \star \star}$ & $(.001)^{\star \star * *}$ & $(.003)^{\star \star \star \star}$ & $(.007)^{\star \star}$ \\
\hline \multirow[t]{2}{*}{ age } & & 2.264 & 2.088 & & 183.979 & 133.389 & & 38.338 & -24.716 & & 20.237 & -6.881 & & 152469.1 & 68686.19 & & -0.004 & -0.003 & & 0.004 & 0.004 \\
\hline & & $(.000)^{\star \star \star \star}$ & $(.001)^{\star \star \star}$ & & $(.599)$ & $(.678)$ & & $(.820)$ & $(.872)$ & & (.634) & (.838) & & $(.028)^{\star \star}$ & (.127) & & (.183) & (.285) & & $(.070)^{\star}$ & $(.073)^{\star}$ \\
\hline \multirow[t]{2}{*}{ export } & & 3.770 & 1.835 & & 7994.545 & 7333.671 & & 3994.575 & 4254.708 & & -170.440 & 39.377 & & 899071.9 & 1317479 & & -0.001 & -0.006 & & 0.196 & 0.196 \\
\hline & & (.839) & $(.923)$ & & (.181) & $(.223)$ & & $(.264)$ & $(.243)$ & & (.848) & $(.963)$ & & $(.525)$ & $(.328)$ & & (.996) & $(.970)$ & & $(.054)^{\star}$ & $(.054)^{\star}$ \\
\hline \multirow[t]{2}{*}{ group } & & 28.890 & 19.673 & & 21645.47 & 21757.45 & & 7093.414 & 7774.974 & & 2319.142 & 2548.224 & & 3295693 & 1974437 & & -0.044 & -0.091 & & -0.129 & -0.128 \\
\hline & & $(.234)$ & $(.397)$ & & (.143) & (.179) & & $(.220)$ & (.220) & & (.147) & $(.144)$ & & $(.204)$ & $(.368)$ & & $(.702)$ & (.457) & & (.155) & (.158) \\
\hline province & & yes & yes & & yes & yes & & yes & yes & & yes & yes & & yes & yes & & yes & yes & & yes & yes \\
\hline industry & & yes & yes & & yes & yes & & yes & yes & & yes & yes & & yes & yes & & yes & yes & & yes & yes \\
\hline obs & 180 & 180 & 174 & 191 & 191 & 185 & 189 & 189 & 183 & 191 & 191 & 185 & 191 & 191 & 185 & 164 & 164 & 155 & 215 & 215 & 207 \\
\hline R2 & .023 & .257 & .240 & .096 & .189 & .180 & .190 & .273 & .250 & .125 & .225 & .178 & .106 & .228 & .177 & .037 & .134 & .100 & .019 & .122 & .122 \\
\hline
\end{tabular}

*** means significant at $1 \%, * \star$ at $5 \%, *$ at $10 \%$. Coeffecients and p-values (in parenthesis) are shown. In the skill intensity equation, marginal effects are shown instead of coefficients. 
TABLE B4: Estimation results under the liberal definition of mutually exclusive sourcing strategies, NS excluded

\begin{tabular}{|c|c|c|c|c|c|c|c|c|c|c|c|c|c|c|c|c|c|c|c|c|c|}
\hline & \multicolumn{3}{|c|}{ employees } & \multicolumn{3}{|c|}{ sales } & \multicolumn{3}{|c|}{ value added } & \multicolumn{3}{|c|}{ profit } & \multicolumn{3}{|c|}{ capital } & \multicolumn{3}{|c|}{ TFP } & \multicolumn{3}{|c|}{ skill intensity } \\
\hline & \multicolumn{3}{|c|}{ OLS estimates } & \multicolumn{3}{|c|}{ OLS estimates } & \multicolumn{3}{|c|}{ OLS estimates } & \multicolumn{3}{|c|}{ OLS estimates } & \multicolumn{3}{|c|}{ OLS estimates } & \multicolumn{3}{|c|}{ OLS estimates } & \multicolumn{3}{|c|}{ Probit estimates } \\
\hline & (1) & (2) & (3) & (1) & (2) & (3) & (1) & (2) & (3) & (1) & (2) & (3) & (1) & (2) & (3) & (1) & (2) & (3) & (1) & (2) & (3) \\
\hline DO_lib_excl & $\begin{array}{l}8.095 \\
(.798)\end{array}$ & $\begin{array}{l}1.798 \\
(.923)\end{array}$ & $\begin{array}{l}5.226 \\
(.774)\end{array}$ & \begin{tabular}{|c}
731.628 \\
$(.923)$
\end{tabular} & $\begin{array}{c}-4437.665 \\
(.583)\end{array}$ & $\begin{array}{c}-3608.043 \\
(.644)\end{array}$ & $\begin{array}{c}2817.334 \\
(.346)\end{array}$ & $\begin{array}{c}806.460 \\
(.811)\end{array}$ & $\begin{array}{c}142.001 \\
(.966)\end{array}$ & \begin{tabular}{|c}
-145.888 \\
$(.866)$
\end{tabular} & $\begin{array}{c}-926.813 \\
(.334)\end{array}$ & $\begin{array}{c}-1023.695 \\
(.267)\end{array}$ & $\begin{array}{c}594605.6 \\
(.712)\end{array}$ & $\begin{array}{c}525488.8 \\
(.745)\end{array}$ & $\begin{array}{c}279237.1 \\
(.851)\end{array}$ & $\begin{array}{l}-0.062 \\
(.649)\end{array}$ & $\begin{array}{l}-0.158 \\
(.300)\end{array}$ & $\begin{array}{l}-0.150 \\
(.333)\end{array}$ & $\begin{array}{l}-0.032 \\
(.737)\end{array}$ & $\begin{array}{l}0.019 \\
(.840)\end{array}$ & $\begin{array}{l}0.024 \\
(.798)\end{array}$ \\
\hline FO_lib_excl & $\begin{array}{l}7.053 \\
(.853)\end{array}$ & $\begin{array}{c}-13.797 \\
(.755)\end{array}$ & $\begin{array}{c}-41.958 \\
(.177)\end{array}$ & \begin{tabular}{|c}
6393.262 \\
$(.620)$
\end{tabular} & $\begin{array}{c}4017.941 \\
(.761)\end{array}$ & $\begin{array}{c}-5348.862 \\
(.474)\end{array}$ & \begin{tabular}{|c}
-560.187 \\
$(.673)$
\end{tabular} & $\begin{array}{c}-666.544 \\
(.850)\end{array}$ & $\begin{array}{c}-388.379 \\
(.913)\end{array}$ & \begin{tabular}{|c}
-132.390 \\
$(.740)$
\end{tabular} & $\begin{array}{c}-441.414 \\
(.623)\end{array}$ & $\begin{array}{c}-125.517 \\
(.869)\end{array}$ & $\begin{array}{c}4474595 \\
(.456)\end{array}$ & $\begin{array}{c}3948371 \\
(.515)\end{array}$ & $\begin{array}{c}-1757999 \\
(.288)\end{array}$ & $\begin{array}{l}-0.072 \\
(.787)\end{array}$ & $\begin{array}{r}-0.122 \\
(.613)\end{array}$ & $\begin{array}{l}-0.117 \\
(.635)\end{array}$ & $\begin{array}{l}-0.032 \\
(.842)\end{array}$ & $\begin{array}{l}-0.082 \\
(.578)\end{array}$ & $\begin{array}{l}-0.074 \\
(.612)\end{array}$ \\
\hline FI_lib_excl & $\begin{array}{l}114.989 \\
(.027)^{\star \star}\end{array}$ & $\begin{array}{l}97.872 \\
(.043)^{\star \star}\end{array}$ & $\begin{array}{l}92.400 \\
(.093)^{\star}\end{array}$ & $\begin{array}{c}68930.25 \\
(.048)^{\star \star}\end{array}$ & $\begin{array}{c}61871.25 \\
(.049)^{\star \star}\end{array}$ & $\begin{array}{c}71473.62 \\
(.069)^{\star}\end{array}$ & $\begin{array}{c}58208.04 \\
(.092)^{\star}\end{array}$ & $\begin{array}{c}53867.53 \\
(.081)^{\star}\end{array}$ & $\begin{array}{c}57503.3 \\
(.147)\end{array}$ & $\begin{array}{c}10423.18 \\
(.089)^{\star}\end{array}$ & $\begin{array}{r}9245.059 \\
(.075)^{\star}\end{array}$ & $\begin{array}{c}7795.521 \\
(.163)\end{array}$ & $\begin{array}{c}1.79 \mathrm{e}+07 \\
(.025)^{\star \star}\end{array}$ & $\begin{array}{c}1.68 \mathrm{e}+07 \\
(.016)^{\star \star}\end{array}$ & $\begin{array}{l}1.47 \mathrm{e}+07 \\
(.036)^{\star \star}\end{array}$ & $\begin{array}{c}0.550 \\
(.031)^{\star \star}\end{array}$ & $\begin{array}{c}0.408 \\
(.023)^{\star \star}\end{array}$ & $\begin{array}{c}0.332 \\
(.054)^{\star}\end{array}$ & $\begin{array}{c}0.600 \\
(.000)^{\star \star \star \star}\end{array}$ & $\begin{array}{c}0.665 \\
(.001)^{\star \star \star}\end{array}$ & $\begin{array}{c}0.484 \\
(.024)^{\star \star}\end{array}$ \\
\hline age & & $\begin{array}{c}2.286 \\
(.000)^{\star \star \star}\end{array}$ & $\begin{array}{c}2.112 \\
(.001)^{\star \star \star}\end{array}$ & & $\begin{array}{c}174.789 \\
(.630)\end{array}$ & $\begin{array}{c}135.915 \\
(.680)\end{array}$ & & $\begin{array}{c}34.767 \\
(.848)\end{array}$ & $\begin{array}{c}-22.336 \\
(.889)\end{array}$ & & $\begin{array}{c}22.509 \\
(.610)\end{array}$ & $\begin{array}{l}-7.122 \\
(.838)\end{array}$ & & $\begin{array}{c}149922.9 \\
(.025)^{\star \star}\end{array}$ & $\begin{array}{c}69798.51 \\
(.124)\end{array}$ & & $\begin{array}{l}-0.004 \\
(.177)\end{array}$ & $\begin{array}{l}-0.004 \\
(.201)\end{array}$ & & $\begin{array}{l}0.003 \\
(.108)\end{array}$ & $\begin{array}{c}0.004 \\
(.095)^{\star}\end{array}$ \\
\hline export & & $\begin{array}{l}4.056 \\
(.827)\end{array}$ & $\begin{array}{l}2.409 \\
(.899)\end{array}$ & & $\begin{array}{c}9684.081 \\
(.121)\end{array}$ & $\begin{array}{c}9281.371 \\
(.138)\end{array}$ & & $\begin{array}{c}3967.326 \\
(.246)\end{array}$ & $\begin{array}{c}4231.892 \\
(.215)\end{array}$ & & $\begin{array}{c}-25.405 \\
(.978)\end{array}$ & $\begin{array}{c}264.645 \\
(.757)\end{array}$ & & $\begin{array}{c}1038087 \\
(.485)\end{array}$ & $\begin{array}{c}1617906 \\
(.257)\end{array}$ & & $\begin{array}{l}-0.007 \\
(.963)\end{array}$ & $\begin{array}{l}-0.012 \\
(.944)\end{array}$ & & $\begin{array}{c}0.215 \\
(.040)^{\star \star}\end{array}$ & $\begin{array}{c}0.210 \\
(.043)^{\star \star}\end{array}$ \\
\hline group & & $\begin{array}{l}26.606 \\
(.275)\end{array}$ & $\begin{array}{c}17.002 \\
(.463)\end{array}$ & & $\begin{array}{c}19681.39 \\
(.162)\end{array}$ & $\begin{array}{c}18681.89 \\
(.210)\end{array}$ & & $\begin{array}{c}6750.085 \\
(.227)\end{array}$ & $\begin{array}{c}7158.679 \\
(.240)\end{array}$ & & $\begin{array}{c}2132.891 \\
(.157)\end{array}$ & $\begin{array}{c}2209.021 \\
(.173)\end{array}$ & & $\begin{array}{c}3088871 \\
(.243)\end{array}$ & $\begin{array}{c}1473514 \\
(.486)\end{array}$ & & $\begin{array}{l}-0.057 \\
(.627)\end{array}$ & $\begin{array}{l}-0.091 \\
(.462)\end{array}$ & & $\begin{array}{l}-0.143 \\
(.125)\end{array}$ & $\begin{array}{l}-0.146 \\
(.111)\end{array}$ \\
\hline $\begin{array}{l}\text { province } \\
\text { industry }\end{array}$ & & $\begin{array}{l}\text { yes } \\
\text { yes }\end{array}$ & $\begin{array}{l}\text { yes } \\
\text { yes }\end{array}$ & & $\begin{array}{l}\text { yes } \\
\text { yes }\end{array}$ & $\begin{array}{l}\text { yes } \\
\text { yes }\end{array}$ & & $\begin{array}{l}\text { yes } \\
\text { yes }\end{array}$ & $\begin{array}{l}\text { yes } \\
\text { yes }\end{array}$ & & $\begin{array}{l}\text { yes } \\
\text { yes }\end{array}$ & $\begin{array}{l}\text { yes } \\
\text { yes }\end{array}$ & & $\begin{array}{l}\text { yes } \\
\text { yes }\end{array}$ & $\begin{array}{l}\text { yes } \\
\text { yes }\end{array}$ & & $\begin{array}{l}\text { yes } \\
\text { yes }\end{array}$ & $\begin{array}{l}\text { yes } \\
\text { yes }\end{array}$ & & $\begin{array}{l}\text { yes } \\
\text { yes }\end{array}$ & $\begin{array}{l}\text { yes } \\
\text { yes }\end{array}$ \\
\hline obs & 180 & 180 & 174 & 191 & 191 & 185 & 189 & 189 & 183 & 191 & 191 & 185 & 191 & 191 & 185 & 164 & 164 & 155 & 215 & 215 & 207 \\
\hline R2 & .022 & .256 & .242 & .075 & 164 & .161 & 182 & .266 & 236 & .119 & 212 & .153 & .095 & .212 & 168 & .035 & .130 & .089 & .029 & .126 & .120 \\
\hline
\end{tabular}

*** means significant at $1 \%,{ }^{* \star}$ at $5 \%, *$ at $10 \%$. Coeffecients and p-values (in parenthesis) are shown. In the skill intensity equation, marginal effects are shown instead of coefficients. 


\section{FIGURES}

\section{FIGURE 1: Question 2.5 in the questionnaire}

For the year 2007, please indicate how your production process - disaggregated by task - is managed, according to the following form. For every task, please, specify whether it is performed intra or extra firm and in which percentage of the total (all percentages in the same column must sum to 100).

\begin{tabular}{|c|c|c|c|c|}
\hline & Input manufacturing & Research \& Development & Final good processing & $\begin{array}{l}\text { Other services } \\
\text { (information, logistics } \\
\text { etc.) }\end{array}$ \\
\hline \multirow[t]{3}{*}{$\begin{array}{l}\text { INTRA } \\
\text { FIRM } \\
\end{array}$} & $\begin{array}{l}\%: \overline{\text { of }} \\
\text { ohich: }\end{array}$ & $\begin{array}{l}\%: \overline{\text { which: }} \\
\text { of }\end{array}$ & $\begin{array}{l}\%: \overline{\text { which: }} \\
\text { of }\end{array}$ & $\begin{array}{l}\%: \overline{\text { which: }} \\
\text { of }\end{array}$ \\
\hline & $\begin{array}{l}\text { Within the boundaries of } \\
\text { your firm or an Italian } \\
\text { affiliate } \\
\% \text { : }\end{array}$ & $\begin{array}{l}\text { Within the boundaries of } \\
\text { your firm or an Italian } \\
\text { affiliate } \\
\% \text { : }\end{array}$ & $\begin{array}{l}\text { Within the boundaries of } \\
\text { your firm or an Italian } \\
\text { affiliate } \\
\% \text { : }\end{array}$ & $\begin{array}{l}\text { Within the boundaries of } \\
\text { your firm or an Italian } \\
\text { affiliate } \\
\% \text { : }\end{array}$ \\
\hline & $\begin{array}{l}\text { Within the boundaries of a } \\
\text { foreign affiliate } \\
\quad \% \text { : }\end{array}$ & $\begin{array}{l}\text { Within the boundaries of a } \\
\text { foreign affiliate } \\
\quad \% \text { : }\end{array}$ & $\begin{array}{l}\text { Within the boundaries of a } \\
\text { foreign affiliate } \\
\% \text { : }\end{array}$ & $\begin{array}{l}\text { Within the boundaries of a } \\
\text { foreign affiliate } \\
\quad \% \text { : }\end{array}$ \\
\hline \multirow[t]{3}{*}{$\begin{array}{l}\text { EXTRA } \\
\text { FIRM } \\
\end{array}$} & $\begin{array}{c}\%: \\
\text { of which: }\end{array}$ & $\begin{array}{c}\%: \\
\text { of which: }\end{array}$ & $\begin{array}{c}\%: \\
\text { of which: }\end{array}$ & $\begin{array}{c}\%: \\
\text { of which: }\end{array}$ \\
\hline & $\begin{array}{l}\text { Within the boundaries of } \\
\text { an independent Italian firm } \\
\% \text { : }\end{array}$ & $\begin{array}{l}\text { Within the boundaries of } \\
\text { an independent Italian firm } \\
\% \text { : }\end{array}$ & $\begin{array}{l}\text { Within the boundaries of } \\
\text { an independent Italian firm } \\
\% \text { : }\end{array}$ & $\begin{array}{l}\text { Within the boundaries of } \\
\text { an independent Italian firm } \\
\% \text { : }\end{array}$ \\
\hline & $\begin{array}{l}\text { Within the boundaries of } \\
\text { an independent foreign } \\
\text { firm } \\
\% \text { : }\end{array}$ & $\begin{array}{l}\text { Within the boundaries of } \\
\text { an independent foreign } \\
\text { firm } \\
\% \text { : }\end{array}$ & $\begin{array}{l}\text { Within the boundaries of } \\
\text { an independent foreign } \\
\text { firm } \\
\% \text { : }\end{array}$ & $\begin{array}{l}\text { Within the boundaries of } \\
\text { an independent foreign } \\
\text { firm } \\
\% \text { : }\end{array}$ \\
\hline
\end{tabular}

FIGURE 2: Sampled firms' mutually inclusive sourcing strategies, conservative versus liberal definition

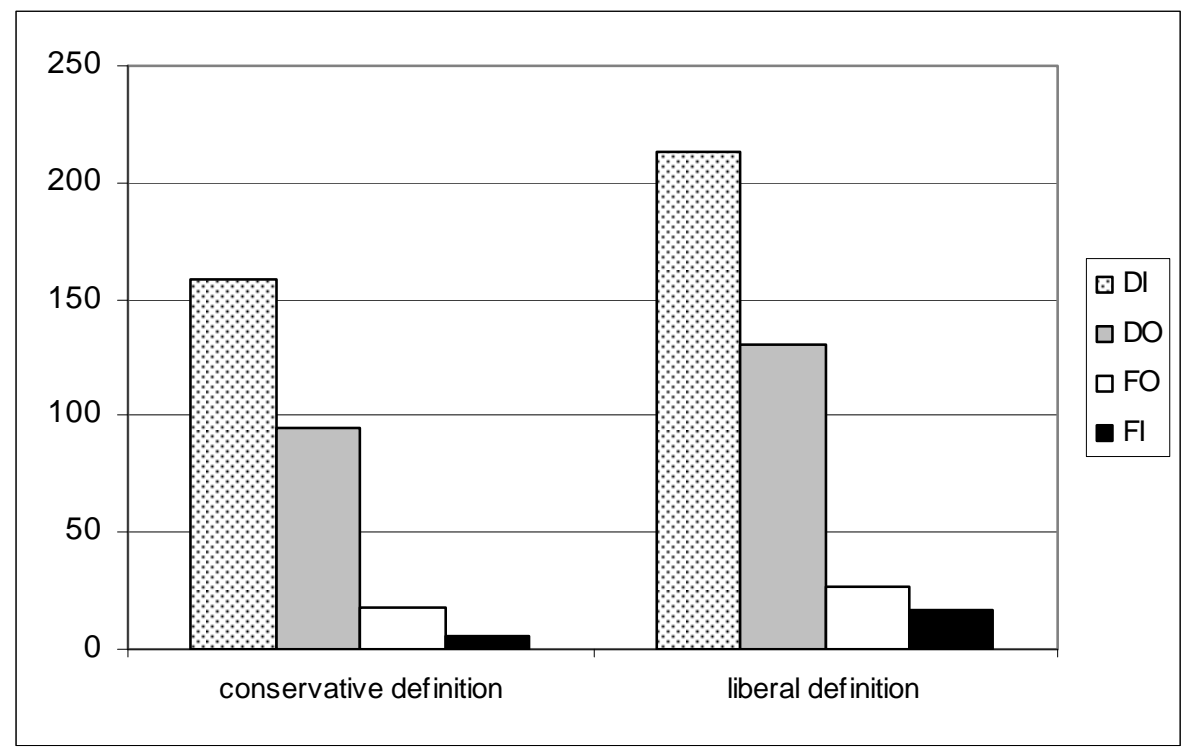


FIGURE 3: Sampled firms' mutually exclusive sourcing strategies, conservative versus liberal definition

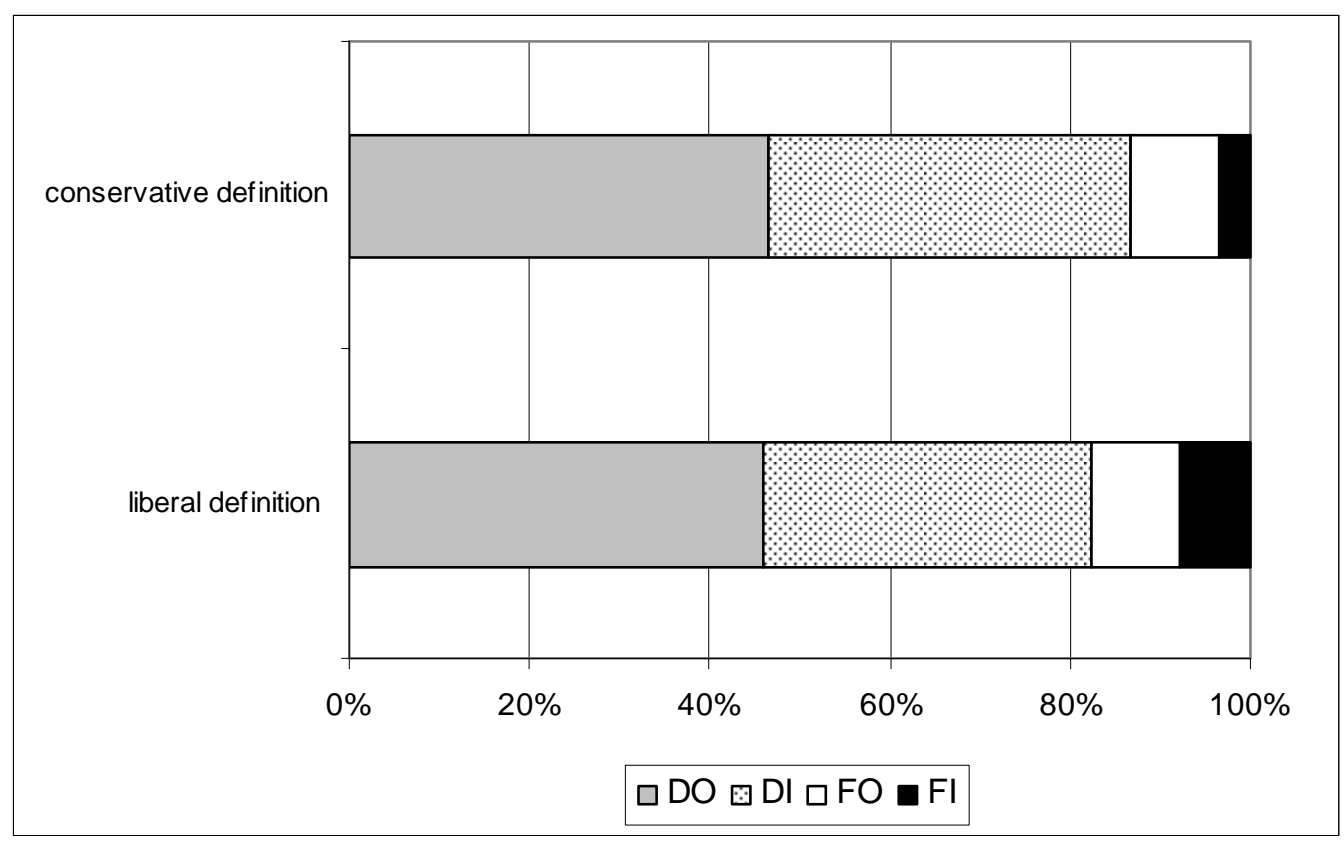

